\title{
Application of Quantile Regression to Examine Changes in the Distribution of Stunting of Indian Children Aged 0-36 Months Using Four Rounds of NFHS Data.
}

Thirupathi Mokalla

ICMR-National Institute of Nutrition

VISHNU VARDHANA MENDU ( $\nabla$ nims.director@icmr.gov.in )

ICMR-National Institute of Medical Statistics

\section{Research Article}

Keywords: Body Mass Index (BMI), Quantile regression, Stunting, Trend, Socioeconomic, Demographic

Posted Date: January 11th, 2021

DOI: https://doi.org/10.21203/rs.3.rs-135050/v1

License: (c) (1) This work is licensed under a Creative Commons Attribution 4.0 International License.

Read Full License 
Application of Quantile Regression to examine changes in the distribution of stunting of Indian children aged 0-36 months using four rounds of NFHS data.

Thirupathi Reddy Mokalla1, Vishnu Vardhana Rao Mendu²*

${ }^{1}$ Senior Research Fellow, Biostatistics, Public Health Nutrition Division, ICMR-National Institute of Nutrition, Jamai-Osmania, Hyderabad - 500007, Telangana, India

Email id: thirupathireddy2423@gmail.com

${ }^{2}$ Scientist G \& Director, ICMR-National Institute of Medical Statistics, Department of Health Research, MOHFW, New Delhi-110029, India

Email id: nims.director@icmr.gov.in

Corresponding author Vishnu Vardhana Rao Mendu, Email id: nims.director@icmr.gov.in 


\title{
Application of Quantile Regression to examine changes in the distribution of stunting of Indian children aged 0-36 months using four rounds of NFHS data.
}

\begin{abstract}
Background: In India, it has been observed that the prevalence of stunting among under-five children decreased, but the prevalence is still alarmingly high. In previous studies, traditional (linear and logistic) regression analyses were used, and these analyses were limited to encapsulated cross-distribution variations. Our study's objective was to examine how the different determinants are heterogenous in various percentiles.
\end{abstract}

Methods: This article examined the change in the stunting distribution of children and examined the relationships between the key covariate's trends and patterns in stunting among children aged $<3$ years over a period of 24 years. Four successive rounds of the National Family Health Survey data 1992-93, 1998-99, 2005-06, and 2015-16 were used for analysis. The final study included 206579 children aged $<3$ years ( $\mathrm{N}=106136$ male, 100443 female). To explain and analyze differences in the stunting distribution, the lambda-mu-sigma (LMS) method was used. Trends in stunting distribution over time were analysed using separate sexstratified quantile regression $(\mathrm{QR})$. The selected socioeconomic, demographic and other predictors considered for this analysis.

Results: The quantile regressions have clearly indicated that mothers who have higher than primary level education were beneficial to decrease child malnutrition at the lower end of the distribution. The age, birth order, mother's body-mass-index (BMI) and wealth, among others, were some more determining factors for HAZ. Results of selected quantile regression estimated at $5^{\text {th }}, 10^{\text {th }}, 25^{\text {th }}, 50^{\text {th }}, 75^{\text {th }}, 90^{\text {th }}$, and $95^{\text {th }}$ quantiles. The wealth index was a highly negative association with lower quantiles compared to upper quantiles in stunting

However, in the age classification, as the age increases, there was a negative association in the upper quantiles of stunting. Small size at birth was having a negative association in all the quantiles of stunting.

Conclusions: The outcome of various covariates working differently across the stunting distribution was suggested by quantile regression. The major discrepancies in different aspects were underlined by socioeconomic and demographic aspects of India. The heterogeneity of this effect was shown using quantile regression.

Keywords: Body Mass Index (BMI); Quantile regression; Stunting; Trend; Socioeconomic; Demographic 


\section{Background}

In India, malnutrition was a significant public health problem among under-five children. The survival and early development of children were severely affected by malnutrition. Also, it vigorously affects the health of pregnant and nursing mothers. The overall resistance-to diseases and future performance in school and at work was also determined by Malnutrition [1, 2]. In the world, among under-five children, about 3.5 million die each year due to child malnutrition. In developing countries, more than one-third of all child deaths under the age of five were mainly caused by child undernutrition [3]. Therefore, nutrition was a significant factor in the health sector, especially in developing countries [4].

The term malnutrition includes undernutrition and overnutrition, and a significant factor causing child mortality worldwide [5]. In child nutritional status, the three broadly known pointers to describe the physical development of children were stunting (short height for age), wasting (low weight for height/length) and underweight (low weight for age) [6 - 8]. Among the children aged 0-59 months, there was a 38\%, 36\%, and $21 \%$ prevalence of stunted children, underweight, and wasting respectively, according to National Family Health Survey (NFHS4) [9]. Around the world, 165 million children under five years of age were affected by stunting [10]. Stunting and other forms of undernutrition reduce a child's chance of survival. It was characterized as the percentage of children aged 0 to 59 months whose height for age was below minus two standard deviations (moderate stunting) and minus three standard deviations (severe stunting) from the median of the WHO Child Growth Standards $[11,12]$. To measure child growth, the height for age Z-score (HAZ) was used.

In early childhood, particularly stunting increases the chance of susceptibility to sickness. Since stunting was associated with suboptimal brain development, it has practically permanent effects on physical, mental development and was probably going to have long-lasting adverse ramifications for intellectual capacity, school performance, and future benefits [10]. The aforementioned effects on development and uniformity caused by child malnutrition were most likely to keep the children in the limbo of poverty, which affects the development of nations $[13,14]$. Thus, improving children's nutritional status and lessening the prevalence of malnutrition to advance their physical and mental improvement was extraordinarily significant [15]. Better wellbeing and nourishment have resulted in financial development just as value concerns $[16,17]$. According to the WHO, stunting was a reliable measure of overall social deprivation [18]. Hence, the World Health Assembly has set a global target to reduce the number of stunted under-five children to 40 percent by $2025[10,13]$. 
Child health was predominantly noteworthy due to its connection to child poverty and the build-up of adult human capital. The improvement of needy children's health and nutrition has been viewed as an effective method of improving school participation and upgrade financial development since learning converts into gains in long-run productivity [19, 20].

There was considerable literature analysing the determinants of nourishing child status in a broad scope of nations and utilizing distinctive econometric techniques. The studies that were conducted earlier have used standard multiple linear or logistic regressions. The more significant part of those past investigations was that they concentrated on finding the determinants at the mean and odds using logistic regression [21 - 27]. The utilization of these methods may prompt inaccurate strategy intercession measures if the relationship between child nutritional status and the specific socioeconomic and demographic determinants is heterogeneous at the various percentiles of the nutritional distribution. Moreover, just a couple of studies focused on the distinction at various points of the conditional nutritional dispersion $[23,28,29]$.

The paper's limitation can be resolved by analysing demographic and socioeconomic factors across varied points of the conditional stunting (HAZ) distribution in India. Moreover, the changes in the stunting distribution of children's and connections between the key covariates patterns and trends in stunting were investigated by using the quantile regression model [30, $31]$.

The objective of this paper was to find the association between demographic, socioeconomic and health factors of child nutritional status from 4 rounds of National Family Health Survey (NFHS) data of children aged $<3$ years in India over 24 years by using quantile regression. Adequate research has not been done in this area. This analysis was expected to improve the structure of successful intercession measures designed to tackle child malnutrition and improve child health.

\section{Methods}

\section{Data}

Data for this analysis were taken from four consecutive rounds of the NFHS of India conducted during 1992-93, 1998-99, 2005-06, and 2015-2016. The NFHS is an expansive scope household study led over the states and union territories of India. The International Institute for Population Sciences (IIPS), Mumbai, India, directed the numerous rounds of the survey with 
community-oriented assistance from a few national and international associations [32]. The surveys conducted led to more information on reliable estimates of fertility, Infant and children mortality, nutritional status of children, better use of $\mathrm{MCH}$ services at a national, state-level and across the urban and rural residence.

The initial three rounds of the NFHS were intended to give state-level information. Nonetheless, the fourth round of study, which includes a more prominent sample size, yields assessments of most factors for all 640 districts in India [9]. Each of the four rounds of the study incorporated multi-stage sampling design, two-stage sampling design in rural areas, and three stages in urban areas [33]. The NFHS gathered information utilizing distinctive interview schedules, household schedules and qualified women/individual schedules, and for the fourth round, the Biomarker Questionnaire was incorporated [9]. In all the rounds, the substance of the schedule remains the same.

The household response rate of the first-round was $96 \%$ and $98 \%$ for the remaining three surveys. The individual response rate for the first and second rounds was $96 \%, 94 \%$ for the third round, while it was $97 \%$ in the fourth round of the survey. All four rounds of the NFHS furnish data on anthropometric pointers with a different age group of children. For instance, NFHS-1 gathered data from children aged below four years and NFHS-2 gathered data from children below three years, while NFHS-3 and 4 gathered data from children below five years. Hence, to make the assessments equivalent, the examination was limited to the children aged $<3$ years old. For this study, in total, only arthrometric indicators of unit-level data of 206579 children aged <3 years $(\mathrm{N}=106136$ male and 100443 female) over 24 years period were considered.

\section{Dependent variable}

In this analysis, only stunting as a dependent variable to find the independent variable's distribution on different quantiles was used. To estimate the stunting marker, the reference population of the WHO 2006[34] was considered. As per the WHO, the child was classified as stunted if the height-for-age Z-score of a child is <2 standard deviations (SDs), then the child was classified as stunted. If the child's $\mathrm{Z}$ score value is $<3$, it was classified as severely stunted. The HAZ score value considered from -6 to +6 remaining cases were excluded/flagged.

\section{Independent variable}

Five quantiles of the socioeconomic variable wealth index have been taken into account in this study. The quantiles are: (poorest, poorer, middle, richer, and richest). Demographic variables such as caste - Scheduled Caste (SC), Scheduled Tribe (ST), Other Backward Class (OBC), and Other castes were taken into consideration. Child characteristics such as child's age in 
months (0-6, 7-12, 13-24, and 25-59), birth order (1,2,3,4, and above), and size at the time of birth (small, average and large) were taken into consideration. The maternal factors include maternal age of 15-49 years, BMI of mothers (underweight: Body mass index <18.5, normal: $18.5<\mathrm{BMI}<25$, and overweight $\mathrm{BMI}>25.0$ ), and mother's education (No education, $<5$ years of schooling, 5-7, 8-9, 10-11, 12 years or more) were considered. The wealth index variable was computed only for the NFHS 3 and 4 due to the NFHS 1 and 2 survey data unavailability for analysis. Moreover, the Body Mass Index (maternal) variable was computed for the NFHS 2, 3 , and 4 due to the unavailability of the data in NFHS 1 .

\section{Statistical Analysis}

\section{Quantile Regression}

Koenker and Bassett (1978) first introduced the key idea of quantile regression [13, 35, 36]. This procedure has an advantage over the conventional common least-squares method. It does not accept a steady effect of the independent factors over the whole distribution of the dependent variable $[31,37]$. This methodology was utilized to consider a heterogeneous impact of every determinant alongside various percentiles of the conditional distribution of the dependent variable [30, 31].

Koenker and Bassett (1978) show that the empirical quantile function is the solution of the minimization problem defined by [37]:

$$
\begin{aligned}
& \hat{\beta}_{\tau}=\underset{\beta_{\tau} \in R^{K}}{\operatorname{argmin}}\left\{\sum_{i: y_{i} \geq x_{i}^{\prime} \beta_{r}} \tau\left|y_{i}-x_{i}^{\prime} \beta_{\tau}\right|+\sum_{i: y_{i}<x_{i}^{\prime} \beta_{r}}(1-\tau)\left|y_{i}-x_{i}^{\prime} \beta_{\tau}\right|\right\} \\
& =\underset{\beta_{\tau} \in R^{K}}{\operatorname{argmin}} \sum_{i} \rho_{\tau}\left|y_{i}-x_{i}^{\prime} \beta_{\tau}\right|
\end{aligned}
$$

With $\rho_{\tau}(z)$ can be defined as:

$$
\rho_{\tau}(z)=\left\{\begin{array}{ll}
\tau(z) & \text { if } z \geq 0 \\
(\tau-1) z & \text { if } z<0
\end{array}=(\tau-I(z<0)) z\right.
$$

Let $x_{i}$ where $\mathrm{i}=1, \ldots, \mathrm{n}$ a sample, a $K \times 1$ vector of regressors, $y_{i}=x_{i}^{\prime} \beta_{\tau}+\varepsilon_{\tau_{i}}, 0<\tau<1$, $\rho_{\tau}(z)$ is the check function, and I(.) usual indicator function.

In this study, quantile regression analysis was performed to identify the independent variables related to child anthropometric $\mathrm{Z}$ score over the seven $\left(5^{\text {th }}, 10^{\text {th }}, 25^{\text {th }}, 50^{\text {th }}, 75^{\text {th }}, 90^{\text {th }}\right.$, and 95 th $)$ percentiles. This analysis was performed using the SAS University Edition software.

\section{Lambda Mu Sigma (LMS) Method}


Using quantile regression, we investigated longitudinal changes in the stunting distribution overtime for the separate sex-stratified. In addition, we used the LMS method to determine the age-specific secular trends in the child nutritional status measures, thereby allowing us to examine the temporal trends in selected seven percentile points of the stunting.

The LMS method summarizes the shifting distribution by three curves representing the median, coefficient of variation and skewness; the latter expressed as a Box-Cox power [38]. For a given value of covariate, to transform the response to standard normality LMS technique applies a Box-Cox transformation; to get the quantiles, an opposite Box-Cox transformation was applied to the quantiles of the standard normal distribution [39, 40]. A large sample size was required to gauge the percentiles in each age group with proper accuracy. The division may lose data from nearby groups. To maintain a strategic distance from division, Cole and Green (1992) built up a Box-Cox transformation based on the semiparametric method from the LMS technique presented by Cole in 1988 [41].

LMS technique in the GAMLSS package R version 3.4.3 (R Development Core Team, Vienna, Austria) to get figures of stunting distribution for 1992 and 2016, along with the lines showing the adjustments in the stunting measures $[42,43]$ were utilized. Additionally, the LMS method to decide the age-specific patterns in the stunting measures for both genders, along with the lines permitting us to analyse the worldly patterns in explicit percentile purposes of the stunting, were utilized in the analysis.

\section{Results}

Table 1. presents descriptive statistics for the individual demographic, socioeconomic, and health-related variables for each gender.

Tables 2 show the calculated coefficients for the selected seven percentiles (5th, 10th, 25th, 50th, 75th, 90th, and 95th) of male and female, HAZ. Table 2 also illustrates that both male and female child age (25-36, 13-24, 7-12 age in months), Mothers education (No education, < 5, 5-7, 8-9 years of schooling), child-size at birth (small, average), birth order (4 or more, three) and type of caste (SC) were negatively associated when compared to their reference category in all percentiles and also found statistically significant. Factors such as child's age in months, child-size at birth, type of caste, and birth order are highly negative associated with higher quantiles than the lower quantile. The factor mother's education (No education and $<5$ years) is high at (10th, 25thand 50th) percentile when compared to other percentiles. Type of caste (ST) had a negative association in (5th, 10th) percentile but a positive association in the higher percentiles (25th, 50th, 75th, 90th, and 95th). 
Tables 3 shows the calculated coefficients at the specific percentiles for both males and females for the NFHS-2 data. Child age (25-36, 13-24, 7-12 age in months), Mothers education (No education, < 5, 5-7, 8-9 years of schooling), child-size at birth (small, average), birth order (three), and type of caste (SC, $\mathrm{OBC}$ ) factors were negatively associated and also statistically significant in all quantiles. The factor mother's education has high coefficient values in lower percentiles and low coefficient values in higher percentiles. The factor birth order ( 4 or more and three) is negatively associated in all except 90th and 95th percentile.

In females, Type of caste (ST) had a negative association in 5th quantile, but a positive association in the higher percentiles (10th, 25th, 50th, 75th, 90th, and 95th), and significant association was observed in (25th, 75th, 90th, and 95th). The factor mothers BMI $(<18.5)$ had a negative association in all percentiles, and it has high coefficient values from 25th to 95th percentile compared to the 5th and 10th percentile. Moreover, a significant association was observed in (25th to 95th) percentile. Similarly, mothers BMI (>25) had a positive association in all quantiles when compared to the reference category (BMI18.5 to 25), Indicating that mothers' BMI is could be an effective measure to combat child stunting.

Table 4 presents the results of quantile regression estimates at the selected percentile levels for the NFHS -3 data. Child's age in months had a statistically significant negative association with HAZ when compared to the reference age group (0-6 months) for both genders, children whose age (25-36, 13-24, 7-12 months) had a high negative association in the higher quantiles when compared to the lower quantiles.

In the maternal education variable, when compared to the reference was taken as mothers had $>12$ years education, mothers education category $(<5,5-7,8-9,10-11$ years $)$ had a statistically significant negative association (except $95 \%$ percentile) with HAZ for both genders. In females, Children whose mother's education had a high negative association at the lower quantiles were switched to low at the higher quantiles (no significant association observed in the $95 \%$ percentile). In male children whose mother's education had a high negative association at the middle quantiles and it is switched to low at the higher quantiles.

For the variable child's size at birth (reference category: Large), child's -size at birth at small and average has a negative association and significant was observed in the male and female children. In male children, it is highly negative associated with the higher quantiles compared to the lower quantiles. In female children, size at birth was less negatively associated in the lower quantiles than the higher quantiles. The type of caste (children who belong to SC and OBC) in male children has negatively statistically significant (10th percentile to 90th 
percentile) associated with the lower quantiles, and it is positively associated in the 95th percentile.

For the female children, type of caste has negatively statistically significant $\left(10^{\text {th }}\right.$ percentile to $90^{\text {th }}$ percentile) associated in the lower quantiles, and it is positively associated in the $95^{\text {th }}$ percentile

For the variable birth order ( 4 or more, three and second) is negatively associated in all except 90thand 95th percentile when compared to the reference category

The quantile regression estimates showed a positive association between BMI>25and HAZ. However, in the lower percentiles, it shows the statistical significance for both genders and in the $95^{\text {th }}$ percentile, no significance was observed. It indicates that Mother's BMI could be an effective measure to combat child stunting.

Quantile regression results presented a statistically significant negative association between household economic status and HAZ. There have been significantly higher HAZ scores of wealth index for children who belong to the poorest, poorer, middle and richer households than the richest household. For example, in 5th percentile, children from the poorest, poorer, middle and richer household's wealth index had a $-0.73,-0.52,-0.40$, and -0.46 disadvantage in terms of height over children from the richest households.

Table 5 presents the results of quantile regression estimates at the selected percentile levels for the NFHS -4 data. Child age in months had a statistically significant (except female at 5th percentile for the age 7-12 months) negative association with HAZ when compared to the reference age group for both genders, children whose age (25-36, 13-24, 7-12 months) had a high negative association in the higher quantiles when compared to the lower quantiles.

Mother's education category $(<5,5-7,8-9,10-11$ years) had a statistically significant negative association (except female at 95\%percentile) with HAZ for both genders.

For the variable child size at birth, child-size at birth at small and average (except 5thpercentile) has a negative association and statistically significant (except both genders at 5th and 10th percentile) was observed in the male and female children. Type of caste (children who belong to $\mathrm{SC}$ and $\mathrm{OBC}$ ) in male children it has negatively statistically significant (except 10th percentile of $\mathrm{OBC}$ ) associated.

For the variable birth order ( 4 or more, three and second), a negatively statistically significant association was observed in all except 90th and 95th percentile compared to the reference category. Also, the higher birth order has a significantly negative association in the lower quantiles of stunting. 
The quantile regression estimates showed a positive association between BMI>25and HAZ. However, in the lower percentiles, it shows the statistical significance for both genders and in the 95th percentile, no significance was observed. It indicates that mother's BMI could be an effective measure to combat child stunting.

Quantile regression results showed a negative association between household economic status and HAZ. Children from the poorest, poorer and middle household's wealth index had higher HAZ scores compared with those from the richest household's wealth index. In particular, children from the poorest, poorer and middle household's wealth index had a $-0.62,-0.48$, and -0.31 disadvantage in terms of height over children from the richest households.

Figure 1 presents the smoothed distribution curve using the LMS method for the differences in the stunting over time in males and females aged 0-36 months in selected years. A decreasing trend is seen in all of the percentile curves from 1992 to 2016, in which the levels are decreased in the higher percentile levels among both genders and each age group. Differentiation of the plots noted that females' stunting percentile curves were marginally stable than those of male children. For both genders, when age increases, it automatically indicates that there are more prone to be stunted, but when compared to the NFHS 1 with NFHS, 4 curves were less decreased.

\section{Discussion}

Using 24 years period of data from the four rounds of NFHS, the determinants associated with stunting and trend in the stunting distribution among children aged 0-36 months of data using quantile regression were identified. The LMS method was used to construct the curves of the $5^{\text {th }}, 10^{\text {th }}, 25^{\text {th }}, 50^{\text {th }}, 75^{\text {th }}, 90^{\text {th }}$, and $95^{\text {th }}$ percentiles. There were significant works investigated the determinants of child nutritional status in a wide scope of nations and utilizing distinctive econometric techniques. Most of the past investigations have generally utilized standard linear regression and logistic regressions. The utilization of these regression estimation techniques may prompt in wrong approach to policy intervention measures, if the relationship between child nutritional status and the different determinants are heterogenous at the various percentiles [44]. One of the most important objectives in developing countries was to decrease child malnutrition. This paper embodied a quantile regression approach to investigate the effects of demographic, socioeconomic and health-related factors on stunting at different percentiles [13].

The analysis identified that the child's age in months is one of the strongest determinants of child nutritional status. Results showed a negative increment in coefficients from lower percentiles to upper percentiles compared to the first six months of life. The analysis also 
reveals that stunting is least in the first six months of life, and it is increased with increasing age $[23,45,46]$.

The present study showed a negative association between the mother's educational status and HAZ. Children of mothers with no education, <5 years. 5-7 years of mother's education had higher negative HAZ scores than the children whose mother's education had >12 years. It was observed that the children of mothers with less education had worse HAZ scores than children of mothers with high education. This analysis has proven that a mother's educational status plays a crucial in child nutrition. Educational accomplishments highly influence the nutritional information, awareness and risks associated with insufficient food. Assessments conducted in the past have revealed that mothers who were educated fed their children better since they have the higher capability and could benefit effectively from health care providers regarding medicinal information and nutrition-rich foods [47-49].

The present study showed a negative association and also statistically significant between household economic status and HAZ. Children from the poorest, poorer, and middle household economic status had higher negative HAZ scores than the richest households. It is observed that the children of low-income families had worse HAZ scores than children from highincome households. The study illustrates that factors like child age, birth order of the child, mother's education and household economic status were more important than aggregate economic conditions [50]. For the factor size at birth, male children whose weight at birth was small had a nutritional drawback in height compared with their best peers.

The mother's nutritional status (BMI) was also associated, and it was statistically significant, with children's nutrition. The results showed a substantial effect on a mother's BMI on a child's nutritional status. Children of mothers with lower BMI are more likely to be stunted when compared with their counterparts.

Strength and limitations of the study

The study showed trends in child nutritional status from 1992 to 2016 using NFHS four rounds of data covering most of India. A more effective approach using quantile regression and LMS method to identify the heterogeneous effect of the child nutritional status with household, socioeconomic and health-related determinants.

Various intervention measures are required to consider the different effects of child nutritional status determinants with various percentiles of the HAZ distribution. Child malnutrition can 
only be tackled with a multifaceted approach that includes targeted intervention, and it cannot be combated with a one-size-fits-all policy [44].

LMS curve with different percentiles for 1992 and 2016 quantified the trends in the performance of genders concerning child nutritional status. This study investigates how factors associated with child nutritional status on the stunting distribution on the selected percentiles. Limitations of the analysis based on secondary data also apply to this study. Cross-section data was used for this study.

\section{Conclusion}

This quantile regression suggests that the effects of different covariates worked differently across the stunting distribution. Predictors of stunting viz: child age in months, birth order, size at birth, and wealth index and their associations vary across different quantiles of stunting in India. Since India's socioeconomic and demographic characteristics have underlined the significant disparities in many aspects, national strategies to tackle stunting should be tailored appropriately for various segments. It would be adequate to carefully integrate applicable interventions according to the objective and target population for individuals' wellbeing and the country's development. Various measures could combat child nutrition among lower socioeconomic strata: increase in the family awareness regarding right feeding practices through mass media or other community-based programs, subsidizing the cost of nutrition-rich food and execute universal health care coverage.

Acknowledgements: The authors gratefully acknowledge the financial support and fellowship granted by the National Institute of Nutrition (NIN), Indian Council of Medical Research, Hyderabad, India, for carrying out the study. The authors wish to thank Dr. R Hemalatha (Director, ICMR-NIN) for her encouragement. The authors would also like to thank Dr. A. Laxmaiah Scientist G \& HOD, Public Health Nutrition Division, ICMR-NIN.

Funding: Not applicable

\section{Availability of data and materials}

The secondary data "NFHS" used in this study are publicly available at https://dhsprogram.com/what-we-do/survey/survey-display-355.cfm

\section{Authors' contributions}

Thirupathi Reddy M contributed to the data collection, analysis, and manuscript preparation. Vishnu Vardhana Rao M developed the study protocol, secured funds, supervised the study, and guided in manuscript preparation. 


\section{Ethics approval and consent to participate}

This study is based on a publicly accessible survey dataset; therefore, this request is not applicable.

\section{Competing interests}

The authors declare that they have no competing interests. 
Table 1 Descriptive Statistics and prevalence of stunting children aged 0-36 months by factors at different categories based on (NFHS- 1, 2, 3, 4) data.

\begin{tabular}{|c|c|c|c|c|c|c|c|c|c|}
\hline \multirow{2}{*}{$\begin{array}{l}\text { Variable (n and \%) } \\
\text { in each category) }\end{array}$} & \multirow{2}{*}{ Category } & \multicolumn{2}{|c|}{ NFHS-1 } & \multicolumn{2}{|c|}{ NFHS-2 } & \multicolumn{2}{|c|}{ NFHS-3 } & \multicolumn{2}{|c|}{ NFHS-4 } \\
\hline & & Female & Male & Female & Male & Female & Male & Female & Male \\
\hline \multirow[t]{5}{*}{ Child age in months } & $25-36$ & $3175(29.8 \%)$ & $3343(30.6 \%)$ & $3581(30.3 \%)$ & $3934(30.5 \%)$ & $4041(33.5 \%)$ & $4456(34.5 \%)$ & $22001(33.4 \%)$ & $23430(33.3 \%)$ \\
\hline & $13-24$ & $3637(34.1 \%)$ & $3730(34.1 \%)$ & $3948(33.4 \%)$ & $4222(32.8 \%)$ & $3945(32.7 \%)$ & $4302(33.3 \%)$ & $21911(33.2 \%)$ & $23273(33.0 \%)$ \\
\hline & $7-12$ & $1663(15.6 \%)$ & $1715(15.7 \%)$ & $1925(16.3 \%)$ & $2118(16.4 \%)$ & $2019(16.8 \%)$ & $2150(16.6 \%)$ & $10881(16.5 \%)$ & $12007(17.1 \%)$ \\
\hline & $0-6$ & $2181(20.5 \%)$ & $2153(19.7 \%)$ & 2373(20.1) & $2611(20.3 \%)$ & 2048(17\%) & $2008(15.5 \%)$ & $11114(16.9 \%)$ & $11684(16.6 \%)$ \\
\hline & Missing & $0(0 \%)$ & $0(0 \%)$ & $0(0 \%)$ & $0(0 \%)$ & $0(0 \%)$ & $0(0 \%)$ & $0(0 \%)$ & $0(0 \%)$ \\
\hline \multirow[t]{5}{*}{ Type of caste } & $\mathrm{SC}$ & $1313(12.3 \%)$ & $1445(13.2 \%)$ & $2156(18.2 \%)$ & $2382(18.5)$ & $2080(17.3 \%)$ & $2292(17.7 \%)$ & $12527(19 \%)$ & $13201(18.8 \%)$ \\
\hline & ST & $1268(11.9 \%)$ & $1262(11.5 \%)$ & $1783(15.1 \%)$ & $1822(14.1 \%)$ & $2018(16.7 \%)$ & $1935(15 \%)$ & $13292(20.2 \%)$ & $13493(19.2 \%)$ \\
\hline & $\mathrm{OBC}$ & - & - & $3419(28.9 \%)$ & $3660(28.4 \%)$ & $3930(32.6 \%)$ & $4262(33 \%)$ & $25747(39.1 \%)$ & $28179(40 \%)$ \\
\hline & Other caste & $8075(75.8 \%)$ & $8234(75.3)$ & $4387(37.1)$ & $4958(38.5 \%)$ & $3513(29.1 \%)$ & $3855(29.8 \%)$ & $11362(17.2 \%)$ & $12478(17.7 \%)$ \\
\hline & Missing & $0(0 \%)$ & $0(0 \%)$ & $82(0.7 \%)$ & $63(0.5 \%)$ & $512(4.3 \%)$ & $572(4.4 \%)$ & $2979(4.5 \%)$ & $3043(4.3 \%)$ \\
\hline \multirow[t]{7}{*}{ Mothers Education } & No education & $5927(55.6 \%)$ & $6143(56.1 \%)$ & $5784(48.9 \%)$ & $6140(47.7 \%)$ & $4731(39.3 \%)$ & $4916(38.1 \%)$ & $19260(29.2 \%)$ & $20041(28.5 \%)$ \\
\hline & $<5$ years & $739(6.9 \%)$ & $703(6.4 \%)$ & $1071(9.1 \%)$ & $1090(8.5 \%)$ & $867(7.2 \%)$ & $911(7.1 \%)$ & $4062(6.2 \%)$ & $4111(5.8 \%)$ \\
\hline & 5-7 years & $1462(13.7 \%)$ & $1409(12.9 \%)$ & $1831(15.5 \%)$ & $1856(14.4 \%)$ & $1932(16 \%)$ & $1946(15.1 \%)$ & $10321(15.7 \%)$ & $11294(16 \%)$ \\
\hline & 8-9 years & $938(8.8 \%)$ & $1068(9.8 \%)$ & $1210(10.2 \%)$ & $1486(11.5 \%)$ & $1812(15 \%)$ & $1965(15.2 \%)$ & $12082(18.3 \%)$ & $13279(18.9 \%)$ \\
\hline & $10-11$ years & $848(8.0 \%)$ & $862(7.9 \%)$ & $997(8.4 \%)$ & $1185(9.2 \%)$ & $1095(9.1 \%)$ & $1383(10.7 \%)$ & 7638(11.6\%) & $8075(11.5 \%)$ \\
\hline & $>12$ years & $703(6.6 \%)$ & $71(6.6 \%)$ & $928(7.8)$ & $1123(8.7 \%)$ & $1616(13.4 \%)$ & $1795(13.9 \%)$ & $12544(19 \%)$ & $13594(19.3 \%)$ \\
\hline & Missing & $39(0.37 \%)$ & $39(0.4 \%)$ & $6(0.05 \%)$ & $5(0.04 \%)$ & $0(0 \%)$ & $0(0 \%)$ & $0(0 \%)$ & $0(0 \%)$ \\
\hline \multirow[t]{4}{*}{ Size at birth } & (Small) & $2369(22.2 \%)$ & $2129(19.5 \%)$ & $3144(26.6 \%)$ & $2970(23.1 \%)$ & $2668(22.1 \%)$ & $2511(19.4 \%)$ & $8333(12.6 \%)$ & $7985(11.3 \%)$ \\
\hline & Average & $6921(64.9 \%)$ & $7177(65.6 \%)$ & $7071(59.8 \%)$ & $7858(61 \%)$ & $6612(54.9 \%)$ & $7214(55.9 \%)$ & $45296(68.7 \%)$ & $48796(69.3 \%)$ \\
\hline & Large & $1266(11.9 \%)$ & $1564(14.3 \%)$ & $1604(13.6 \%)$ & $2051(15.9 \%)$ & $2605(21.6 \%)$ & $3021(23.4 \%)$ & $10991(16.7 \%)$ & $12349(17.5 \%)$ \\
\hline & Missing & $100(0.9 \%)$ & $71(0.6 \%)$ & $8(0.07 \%)$ & $6(0.05 \%)$ & $168(1.4 \%)$ & $170(1.3 \%)$ & $1287(2 \%)$ & $1264(1.8 \%)$ \\
\hline \multirow[t]{5}{*}{ Birth order } & 4 or more & $3130(29.4 \%)$ & $3270(29.9 \%)$ & $3090(26.1)$ & $3395(26.3 \%)$ & $2712(22.5 \%)$ & $2893(22.4 \%)$ & $10122(15.4 \%)$ & $10800(15.3 \%)$ \\
\hline & Three & $1918(18 \%)$ & $1951(17.8 \%)$ & $2061(17.4 \%)$ & $2286(17.7 \%)$ & 1911(15.9\%) & $2147(16.6 \%)$ & $10127(15.4 \%)$ & $11487(16.3 \%)$ \\
\hline & Second & $2669(25 \%)$ & $2668(24.4 \%)$ & $3126(26.4 \%)$ & $3467(26.9 \%)$ & $3445(28.6 \%)$ & $3762(29.1)$ & 20912(31.7\%) & $22162(31.5 \%)$ \\
\hline & First & $2939(27.6 \%)$ & $3052(27.9 \%)$ & $3550(30 \%)$ & $3737(29 \%)$ & $3985(33.1 \%)$ & $4114(31.9 \%)$ & $24746(37.5 \%)$ & $25945(36.9 \%)$ \\
\hline & Missing & $0(0 \%)$ & $0(0 \%)$ & $0(0 \%)$ & $0(0 \%)$ & $0(0 \%)$ & $0(0 \%)$ & $0(0 \%)$ & $0(0 \%)$ \\
\hline \multirow[t]{6}{*}{ Wealth Index } & Poorest & - & - & - & - & $2165(18 \%)$ & $2171(16.8 \%)$ & $16886(25.6 \%)$ & $17645(25.1 \%)$ \\
\hline & Poorer & - & - & - & - & $2288(19 \%)$ & $2256(17.5 \%)$ & $15704(23.8 \%)$ & $16535(23.5 \%)$ \\
\hline & Middle & - & - & - & - & $2487(20.6 \%)$ & $2692(20.8 \%)$ & $13318(20.2 \%)$ & $14374(20.4 \%)$ \\
\hline & Richer & - & - & - & - & $2689(22.3 \%)$ & $2948(22.8 \%)$ & $11254(17.1 \%)$ & $11886(16.9 \%)$ \\
\hline & Richest & - & - & - & - & $2424(20.1 \%)$ & $2849(22.1 \%)$ & $8745(13.3)$ & $9954(14.1 \%)$ \\
\hline & Missing & - & - & - & - & $0(0 \%)$ & $0(0 \%)$ & $0(0 \%)$ & $0(0 \%)$ \\
\hline \multirow[t]{4}{*}{ Mothers BMI } & $<18.5$ & - & - & $4152(35.1 \%)$ & $4661(36.2 \%)$ & $3970(32.9 \%)$ & $4276(33 \%)$ & $16004(24.3 \%)$ & $17596(25 \%)$ \\
\hline & BMI $>25$ & - & - & $668(5.6 \%)$ & $699(5.4 \%)$ & $1044(8.7 \%)$ & $1208(9.4 \%)$ & $8377(12.7 \%)$ & $8972(12.7 \%)$ \\
\hline & BMI 18.5-25 & - & - & $6957(58.8 \%)$ & $7456(57.9 \%)$ & $6959(57.7)$ & 7371(57) & $41113(62.4 \%)$ & $43421(61.7 \%)$ \\
\hline & Missing & - & - & $50(0.4 \%)$ & $69(0.5 \%)$ & $80(0.7 \%)$ & $61(0.5 \%)$ & $413(0.6 \%)$ & $405(0.6 \%)$ \\
\hline
\end{tabular}


Table 2: Quantile Regression Estimations for the different quantiles of the female (10517) and male (10830) children's, Dependent variable HAZ (Stunting) NFHS-1

\begin{tabular}{|c|c|c|c|c|c|c|c|c|c|c|c|c|c|c|}
\hline \multirow{2}{*}{ Parameter } & \multicolumn{2}{|l|}{0.05} & \multicolumn{2}{|l|}{0.1} & \multicolumn{2}{|l|}{0.25} & \multicolumn{2}{|l|}{0.5} & \multicolumn{2}{|l|}{0.75} & \multicolumn{2}{|l|}{0.9} & \multicolumn{2}{|l|}{0.95} \\
\hline & Female & Male & Female & Male & Female & Male & Female & Male & Female & Male & Female & Male & Female & Male \\
\hline Intercept & $-3.31^{a}$ & $-3.82^{a}$ & $-2.12^{a}$ & $-2.45^{\mathrm{a}}$ & $-0.73^{a}$ & $-1.11^{\mathrm{a}}$ & $0.30^{\mathrm{a}}$ & $0.018^{\mathrm{a}}$ & $1.18^{\mathrm{a}}$ & $1.30^{\mathrm{a}}$ & $2.40^{\mathrm{a}}$ & $2.38^{\mathrm{a}}$ & $3.25^{\mathrm{a}}$ & $2.98^{\mathrm{a}}$ \\
\hline \multicolumn{15}{|l|}{ Child age in Months } \\
\hline 25-36in Months & $-0.97^{\mathrm{a}}$ & $-0.63^{a}$ & $-1.38^{\mathrm{a}}$ & $-0.94^{\mathrm{a}}$ & $-1.7^{\mathrm{a}}$ & $-1.28^{\mathrm{a}}$ & $-1.75^{\mathrm{a}}$ & $-1.56^{\mathrm{a}}$ & $-1.80^{\mathrm{a}}$ & $-1.8^{\mathrm{a}}$ & $-1.89^{a}$ & $-1.93^{\mathrm{a}}$ & $-2.00^{\mathrm{a}}$ & $-1.80^{\mathrm{a}}$ \\
\hline 13-24 months & $-0.68^{\mathrm{a}}$ & $-0.52^{a}$ & $-1.01^{a}$ & $-0.80^{\mathrm{a}}$ & $-1.32^{\mathrm{a}}$ & $-1.08^{\mathrm{a}}$ & $-1.40^{\mathrm{a}}$ & $-1.35^{\mathrm{a}}$ & $-1.40^{\mathrm{a}}$ & $-1.52^{\mathrm{a}}$ & $-1.55^{\mathrm{a}}$ & $-1.63^{\mathrm{a}}$ & $-1.57^{a}$ & $-1.48^{\mathrm{a}}$ \\
\hline 7-12 months & $-0.32^{a}$ & $-0.25^{\mathrm{b}}$ & $-0.50^{\mathrm{a}}$ & $-0.33^{\mathrm{a}}$ & $-0.56^{a}$ & $-0.40^{\mathrm{a}}$ & $-0.64^{a}$ & $-0.50^{\mathrm{a}}$ & $-0.71^{a}$ & $-0.67^{a}$ & $-0.79^{a}$ & $-0.78^{\mathrm{a}}$ & $-0.95^{\mathrm{a}}$ & $-0.67^{a}$ \\
\hline 0-6 months & Reference & Reference & Reference & Reference & Reference & Reference & Reference & Reference & Reference & Reference & Reference & Reference & Reference & Reference \\
\hline \multicolumn{15}{|l|}{ Mothers Education } \\
\hline No education & $-0.68^{\mathrm{a}}$ & $-0.73^{a}$ & $-1.03^{\mathrm{a}}$ & $-1.13^{\mathrm{a}}$ & $-1.21^{\mathrm{a}}$ & $-1.26^{a}$ & $-1.05^{\mathrm{a}}$ & $-1.11^{\mathrm{a}}$ & $-0.76^{a}$ & $-1.09^{\mathrm{a}}$ & $-0.74^{a}$ & $-0.82^{\mathrm{a}}$ & $-0.46^{b}$ & $-0.59^{\mathrm{a}}$ \\
\hline$<5$ years & $-0.33^{\mathrm{a}}$ & -0.21 & $-0.55^{\mathrm{a}}$ & $-0.49^{a}$ & $-0.82^{a}$ & $-0.77^{a}$ & $-0.81^{a}$ & $-0.80^{\mathrm{a}}$ & $-0.67^{\mathrm{a}}$ & $-0.77^{\mathrm{a}}$ & $-0.70^{\mathrm{a}}$ & $-0.70^{\mathrm{a}}$ & $-0.60^{b}$ & -0.48 \\
\hline 5-7 years & -0.14 & $-0.27^{c}$ & $-0.35^{\mathrm{a}}$ & $-0.60^{a}$ & $-0.59^{a}$ & $-0.70^{\mathrm{a}}$ & $-0.61^{a}$ & $-0.62^{a}$ & $-0.44^{a}$ & $-0.73^{a}$ & $-0.60^{a}$ & $-0.57^{\mathrm{a}}$ & $-0.43^{c}$ & -0.39 \\
\hline 8-9 years & -0.02 & -0.03 & $-0.36^{a}$ & $-0.26^{\mathrm{c}}$ & $-0.45^{\mathrm{a}}$ & $-0.49^{\mathrm{a}}$ & $-0.47^{a}$ & $-0.44^{a}$ & $-0.29^{a}$ & $-0.49^{\mathrm{a}}$ & $-0.55^{\mathrm{a}}$ & $-0.67^{a}$ & $-0.68^{\mathrm{a}}$ & $-0.63^{b}$ \\
\hline $10-11$ years & -0.05 & 0.09 & -0.006 & -0.05 & $-0.23^{b}$ & -0.25 & $-0.16^{\mathrm{c}}$ & $-0.25^{\mathrm{a}}$ & -0.02 & $-0.29^{\mathrm{a}}$ & -0.21 & $-0.33^{c}$ & 0.25 & -0.17 \\
\hline$>12$ years & Reference & Reference & Reference & Reference & Reference & Reference & Reference & Reference & Reference & Reference & Reference & Reference & Reference & Reference \\
\hline \multicolumn{15}{|l|}{ Size at birth } \\
\hline Small & $-0.35^{\mathrm{a}}$ & $-0.21^{\mathrm{c}}$ & $-0.34^{a}$ & $-0.50^{a}$ & $-0.45^{\mathrm{a}}$ & $-0.48^{a}$ & $-0.53 \mathrm{a}^{\mathrm{a}}$ & $-0.58^{a}$ & $-0.57^{a}$ & $-0.63^{\mathrm{a}}$ & $-0.69^{a}$ & $-0.62^{a}$ & $-0.94^{a}$ & $-0.69^{a}$ \\
\hline Average & $-0.22^{\mathrm{b}}$ & -0.04 & $-0.24^{a}$ & $-0.23^{\mathrm{a}}$ & $-0.23^{\mathrm{a}}$ & $-0.17^{a}$ & $-0.29^{\mathrm{a}}$ & $-0.28^{\mathrm{a}}$ & $-0.32^{\mathrm{a}}$ & $-0.28^{\mathrm{a}}$ & $-0.39^{\mathrm{a}}$ & $-0.31^{\mathrm{a}}$ & $-0.39^{\mathrm{b}}$ & $-0.39^{\mathrm{b}}$ \\
\hline Large & Reference & Reference & Reference & Reference & Reference & Reference & Reference & Reference & Reference & Reference & Reference & Reference & Reference & Reference \\
\hline \multicolumn{15}{|l|}{ Type of caste } \\
\hline (SC) & -0.05 & -0.06 & -0.11 & $-0.17^{b}$ & $-0.15^{b}$ & $-0.18^{a}$ & $-0.13^{b}$ & $-0.15^{a}$ & $-0.23^{a}$ & $-0.12^{c}$ & $-0.18^{b}$ & -0.06 & -0.17 & -0.13 \\
\hline ST & $-0.33^{\mathrm{a}}$ & $-0.21^{\mathrm{c}}$ & -0.12 & $-0.16^{c}$ & $0.12^{\mathrm{c}}$ & -0.07 & $0.17^{\mathrm{a}}$ & $0.09^{\mathrm{c}}$ & $0.24^{\mathrm{a}}$ & $0.31^{\mathrm{a}}$ & $0.53^{\mathrm{a}}$ & $0.58^{\mathrm{a}}$ & $0.93^{\mathrm{a}}$ & $1.03^{\mathrm{a}}$ \\
\hline Other caste & Reference & Reference & Reference & Reference & Reference & Reference & Reference & Reference & Reference & Reference & Reference & Reference & Reference & Reference \\
\hline \multicolumn{15}{|l|}{ Birth order } \\
\hline 4 or more & -0.13 & $-0.19^{b}$ & $-0.14^{b}$ & -0.12 & $-0.15^{b}$ & -0.08 & $-0.13^{\mathrm{a}}$ & $-0.08^{c}$ & $-0.13^{b}$ & -0.04 & -0.001 & -0.11 & -0.09 & -0.15 \\
\hline Three & -0.07 & -0.03 & -0.03 & -0.06 & 0.04 & 0.004 & -0.02 & -0.003 & $-0.11^{c}$ & -0.08 & -0.11 & -0.1 & $-0.33^{b}$ & -0.04 \\
\hline Second & -0.03 & 0.02 & 0.01 & 0.04 & 0.05 & 0.04 & 0 & 0.01 & -0.02 & 0.04 & -0.01 & 0.06 & -0.11 & 0.1 \\
\hline First & Reference & Reference & Reference & Reference & Reference & Reference & Reference & Reference & Reference & Reference & Reference & Reference & Reference & Reference \\
\hline
\end{tabular}

a: $1 \%$ Significance; b: $5 \%$ Significance; c: $10 \%$ Significance 
Table 3: Quantile Regression Estimations for the different quantiles of the female (11582) and Male (12742) children's, Dependent variable HAZ (Stunting) NFHS-2

\begin{tabular}{|c|c|c|c|c|c|c|c|c|c|c|c|c|c|c|}
\hline \multirow[t]{2}{*}{ Parameter } & \multicolumn{2}{|c|}{0.05} & \multicolumn{2}{|c|}{0.1} & \multicolumn{2}{|c|}{0.25} & \multicolumn{2}{|c|}{0.50} & \multicolumn{2}{|c|}{0.75} & \multicolumn{2}{|c|}{0.9} & \multicolumn{2}{|c|}{0.95} \\
\hline & Female & Male & Female & Male & Female & Male & Female & Male & Female & Male & Female & Male & Female & Male \\
\hline $\begin{array}{l}\text { Intercept } \\
\text { Child age }\end{array}$ & $-1.99^{a}$ & $-2.29^{a}$ & -1.48 & $-1.50^{\mathrm{a}}$ & $-0.57^{a}$ & $-0.59^{a}$ & $0.53^{\mathrm{a}}$ & $0.41^{\mathrm{a}}$ & $1.38^{\mathrm{a}}$ & $1.41^{\mathrm{a}}$ & $2.41^{\mathrm{a}}$ & $2.69^{\mathrm{a}}$ & $2.98^{\mathrm{a}}$ & $3.29^{\mathrm{a}}$ \\
\hline 25-36in Months & $-1.75^{\mathrm{a}}$ & $-1.32^{\mathrm{a}}$ & $-1.81^{\mathrm{a}}$ & $-1.48^{\mathrm{a}}$ & $-1.75^{\mathrm{a}}$ & $-1.51^{\mathrm{a}}$ & $-1.87^{a}$ & $-1.63^{\mathrm{a}}$ & $-2.02^{\mathrm{a}}$ & $-1.89^{a}$ & $-2.20^{\mathrm{a}}$ & $-2.24^{\mathrm{a}}$ & $-2.17^{\mathrm{a}}$ & $-2.28^{\mathrm{a}}$ \\
\hline 13-24 months & $-1.52^{\mathrm{a}}$ & $-1.20^{\mathrm{a}}$ & $-1.45^{\mathrm{a}}$ & $-1.33^{\mathrm{a}}$ & $-1.41^{\mathrm{a}}$ & $-1.41^{\mathrm{a}}$ & $-1.51^{\mathrm{a}}$ & $-1.53^{\mathrm{a}}$ & $-1.72^{\mathrm{a}}$ & $-1.64^{\mathrm{a}}$ & $-1.87^{a}$ & $-1.95^{\mathrm{a}}$ & $-1.93^{\mathrm{a}}$ & $-1.93^{\mathrm{a}}$ \\
\hline 7-12 months & $-0.48^{a}$ & $-0.54^{\mathrm{a}}$ & $-0.51^{\mathrm{a}}$ & $-0.59^{a}$ & $-0.62^{\mathrm{a}}$ & $-0.61^{\mathrm{a}}$ & $-0.69^{a}$ & $-0.67^{\mathrm{a}}$ & $-0.84^{\mathrm{a}}$ & $-0.78^{\mathrm{a}}$ & $-1.01^{\mathrm{a}}$ & $-1.03^{\mathrm{a}}$ & $-1.01^{\mathrm{a}}$ & $-0.96^{\mathrm{a}}$ \\
\hline $\begin{array}{c}0-6 \text { months } \\
\text { Mothers Education }\end{array}$ & Reference & Reference & Reference & Reference & Reference & Reference & Reference & Reference & Reference & Reference & Reference & Reference & Reference & Reference \\
\hline No education & $-1.22^{\mathrm{a}}$ & $-1.15^{\mathrm{a}}$ & $-1.21^{\mathrm{a}}$ & $-1.18^{\mathrm{a}}$ & $-1.11^{\mathrm{a}}$ & $-1.20^{\mathrm{a}}$ & $-1.04^{a}$ & $-0.98^{\mathrm{a}}$ & $-0.82^{\mathrm{a}}$ & $-0.86^{a}$ & $-0.66^{\mathrm{a}}$ & $-0.76^{\mathrm{a}}$ & $-0.38^{b}$ & $-0.61^{\mathrm{a}}$ \\
\hline$<5$ years & $-0.95^{\mathrm{a}}$ & $-0.79^{\mathrm{a}}$ & $-0.87^{a}$ & $-0.74^{\mathrm{a}}$ & $-0.69^{a}$ & $-0.81^{\mathrm{a}}$ & $-0.69^{a}$ & $-0.65^{\mathrm{a}}$ & $-0.51^{a}$ & $-0.64^{\mathrm{a}}$ & $-0.43^{\mathrm{a}}$ & $-0.77^{\mathrm{a}}$ & -0.31 & $-0.55^{\mathrm{a}}$ \\
\hline 5-7 years & $-0.52^{\mathrm{a}}$ & $-0.73^{\mathrm{a}}$ & $-0.54^{a}$ & $-0.81^{\mathrm{a}}$ & $-0.55^{\mathrm{a}}$ & $-0.71^{a}$ & $-0.57^{a}$ & $-0.67^{\mathrm{a}}$ & $-0.50^{\mathrm{a}}$ & $-0.55^{\mathrm{a}}$ & $-0.41^{\mathrm{a}}$ & $-0.60^{\mathrm{a}}$ & -0.23 & $-0.57^{\mathrm{a}}$ \\
\hline $8-9$ years & $-0.64^{\mathrm{a}}$ & $-0.52^{\mathrm{a}}$ & $-0.52^{\mathrm{a}}$ & $-0.49^{\mathrm{a}}$ & $-0.40^{\mathrm{a}}$ & $-0.49^{\mathrm{a}}$ & $-0.48^{\mathrm{a}}$ & $-0.37^{\mathrm{a}}$ & $-0.33^{\mathrm{a}}$ & $-0.33^{\mathrm{a}}$ & $-0.30^{\mathrm{b}}$ & $-0.42^{\mathrm{a}}$ & -0.1 & $-0.42^{\mathrm{b}}$ \\
\hline $10-11$ years & $-0.50^{\mathrm{a}}$ & $-0.46^{\mathrm{a}}$ & $-0.28^{\mathrm{b}}$ & $-0.35^{\mathrm{a}}$ & $-0.30^{\mathrm{a}}$ & $-0.35^{\mathrm{a}}$ & $-0.33^{\mathrm{a}}$ & $-0.25^{\mathrm{a}}$ & $-0.17^{c}$ & -0.2 & -0.15 & -0.19 & -0.1 & $-0.30^{c}$ \\
\hline $\begin{array}{l}\quad>12 \text { years } \\
\text { Size at birth }\end{array}$ & Reference & Reference & Reference & Reference & Reference & Reference & Reference & Reference & Reference & Reference & Reference & Reference & Reference & Reference \\
\hline Small & $-0.42^{\mathrm{a}}$ & $-0.53^{\mathrm{a}}$ & $-0.45^{\mathrm{a}}$ & $-0.56^{\mathrm{a}}$ & $-0.55^{\mathrm{a}}$ & $-0.57^{\mathrm{a}}$ & $-0.60^{\mathrm{a}}$ & $-0.59^{\mathrm{a}}$ & $-0.52^{\mathrm{a}}$ & $-0.56^{a}$ & $-0.50^{\mathrm{a}}$ & $-0.61^{\mathrm{a}}$ & $-0.49^{\mathrm{a}}$ & $-0.55^{\mathrm{a}}$ \\
\hline Average & $-0.16^{\mathrm{c}}$ & $-0.27^{\mathrm{a}}$ & $-0.13^{c}$ & $-0.33^{\mathrm{a}}$ & $-0.24^{\mathrm{a}}$ & $-0.34^{\mathrm{a}}$ & $-0.28^{a}$ & $-0.32^{\mathrm{a}}$ & $-0.22^{\mathrm{a}}$ & $-0.32^{\mathrm{a}}$ & $-0.26^{\mathrm{a}}$ & $-0.42^{\mathrm{a}}$ & $-0.23^{c}$ & $-0.36^{\mathrm{a}}$ \\
\hline $\begin{array}{l}\text { Large } \\
\text { Type of cast }\end{array}$ & Reference & Reference & Reference & Reference & Reference & Reference & Reference & Reference & Reference & Reference & Reference & Reference & Reference & Reference \\
\hline $\mathrm{SC}$ & $-0.21^{\mathrm{a}}$ & $-0.18^{b}$ & $-0.16^{\mathrm{b}}$ & $-0.27^{\mathrm{a}}$ & $-0.19^{\mathrm{a}}$ & $-0.23^{\mathrm{a}}$ & $-0.19^{a}$ & $-0.29^{\mathrm{a}}$ & $-0.18^{\mathrm{a}}$ & $-0.21^{\mathrm{a}}$ & $-0.20^{\mathrm{a}}$ & $-0.26^{\mathrm{a}}$ & $-0.27^{b}$ & $-0.26^{\mathrm{b}}$ \\
\hline ST & -0.06 & $-0.18^{c}$ & 0.01 & $-0.25^{\mathrm{a}}$ & $0.12^{\mathrm{b}}$ & $-0.14^{b}$ & 0.056 & $-0.13^{\mathrm{a}}$ & $0.15^{\mathrm{b}}$ & $-0.04^{\mathrm{c}}$ & $0.16^{\mathrm{b}}$ & $0.14^{c}$ & $0.30^{\mathrm{b}}$ & $0.43^{\mathrm{a}}$ \\
\hline OBC & -0.07 & $-0.22^{\mathrm{a}}$ & $-0.14^{\mathrm{b}}$ & $-0.25^{\mathrm{a}}$ & -0.05 & $-0.11^{\mathrm{b}}$ & -0.05 & $-0.08^{c}$ & $-0.09^{c}$ & -0.04 & $-0.13^{c}$ & -0.07 & $-0.20^{\mathrm{c}}$ & -0.03 \\
\hline $\begin{array}{l}\text { Other caste } \\
\text { Birth order }\end{array}$ & Reference & Reference & Reference & Reference & Reference & Reference & Reference & Reference & Reference & Reference & Reference & Reference & Reference & Reference \\
\hline 4 or more & $-0.29^{\mathrm{a}}$ & $-0.22^{\mathrm{a}}$ & $-0.31^{\mathrm{a}}$ & $-0.25^{\mathrm{a}}$ & $-0.33^{\mathrm{a}}$ & $-0.23^{\mathrm{a}}$ & $-0.29^{\mathrm{a}}$ & $-0.23^{\mathrm{a}}$ & $-0.17^{\mathrm{a}}$ & -0.13 & 0.03 & 0.05 & $0.29^{\mathrm{b}}$ & 0.17 \\
\hline Three & -0.12 & -0.04 & -0.08 & $-0.11^{\mathrm{c}}$ & $-0.13^{\mathrm{b}}$ & -0.08 & $-0.18^{a}$ & $-0.09^{c}$ & -0.61 & $-0.11^{\mathrm{c}}$ & -0.02 & $-0.14^{\mathrm{c}}$ & -0.06 & $-0.20^{c}$ \\
\hline Second & -0.1 & -0.0575 & -0.1 & -0.067 & $-0.08^{c}$ & -0.04 & $-0.11^{\mathrm{b}}$ & -0.06 & -0.07 & -0.05 & 0.03 & -0.03 & -0.03 & 0.08 \\
\hline $\begin{array}{r}\text { First } \\
\text { Mothers BMI }\end{array}$ & Reference & Reference & Reference & Reference & Reference & Reference & Reference & Reference & Reference & Reference & Reference & Reference & Reference & Reference \\
\hline BMI $<18.5$ & -0.01 & -0.07 & -0.05 & -0.07 & $-0.08^{b}$ & $-0.09^{\mathrm{a}}$ & $-0.09^{\mathrm{a}}$ & $-0.17^{\mathrm{a}}$ & $-0.17^{\mathrm{a}}$ & $-0.24^{\mathrm{a}}$ & $-0.28^{\mathrm{a}}$ & $-0.28^{\mathrm{a}}$ & $-0.44^{\mathrm{a}}$ & $-0.50^{\mathrm{a}}$ \\
\hline BMI $>25$ & $0.40^{\mathrm{a}}$ & 0.2 & $0.37^{\mathrm{a}}$ & $0.27^{\mathrm{a}}$ & $0.51^{\mathrm{a}}$ & $0.29^{\mathrm{a}}$ & $0.428^{\mathrm{a}}$ & $0.24^{\mathrm{a}}$ & $0.40^{\mathrm{a}}$ & $0.28^{\mathrm{b}}$ & $0.36^{\mathrm{a}}$ & $0.28^{\mathrm{b}}$ & 0.19 & 0.23 \\
\hline BMI $18.5-25$ & Reference & Reference & Reference & Reference & Reference & Reference & Reference & Reference & Reference & Reference & Reference & Reference & Reference & Reference \\
\hline
\end{tabular}

a: $1 \%$ Significance; b: $5 \%$ Significance; c: $10 \%$ Significance 
Table 4: Quantile Regression Estimations for the different quantiles of the female (11315) and male (12133) children's, Dependent variable HAZ (Stunting) NFHS-3

\begin{tabular}{|c|c|c|c|c|c|c|c|c|c|c|c|c|c|c|}
\hline Parameter & & & & & & & & & & & & & & \\
\hline & Female & Male & Female & Male & Female & Male & Female & Male & Female & Male & Female & Male & Female & Male \\
\hline $\begin{array}{l}\text { Intercept } \\
\text { Child age in months }\end{array}$ & $-2.18^{\mathrm{a}}$ & $-2.43^{a}$ & $-1.51^{\mathrm{a}}$ & $-1.68^{a}$ & $-0.50^{\mathrm{a}}$ & $-0.54^{a}$ & $0.47^{\mathrm{a}}$ & $0.58^{\mathrm{a}}$ & $1.40^{\mathrm{a}}$ & $1.55^{\mathrm{a}}$ & $2.19^{\mathrm{a}}$ & $2.44^{\mathrm{a}}$ & $2.95^{\mathrm{a}}$ & $2.96^{\mathrm{a}}$ \\
\hline 25-36in Months & $-0.86^{\mathrm{a}}$ & $-0.89^{\mathrm{a}}$ & $-1.05^{\mathrm{a}}$ & $-1.02^{\mathrm{a}}$ & $-1.36^{\mathrm{a}}$ & $-1.28^{\mathrm{a}}$ & $-1.51^{a}$ & $-1.47^{a}$ & $-1.68^{\mathrm{a}}$ & $-1.67^{\mathrm{a}}$ & $-1.67^{\mathrm{a}}$ & $-1.72^{\mathrm{a}}$ & $-1.88^{\mathrm{a}}$ & $-1.56^{\mathrm{a}}$ \\
\hline 13-24 months & $-0.86^{a}$ & $-0.87^{a}$ & $-0.98^{a}$ & $-1.01^{\mathrm{a}}$ & $-1.26^{\mathrm{a}}$ & $-1.28^{\mathrm{a}}$ & $-1.42^{\mathrm{a}}$ & $-1.45^{\mathrm{a}}$ & $-1.58^{a}$ & $-1.58^{\mathrm{a}}$ & $-1.59^{a}$ & $-1.59^{\mathrm{a}}$ & $-1.74^{\mathrm{a}}$ & $-1.41^{\mathrm{a}}$ \\
\hline 7-12 months & -0.16 & $-0.26^{\mathrm{b}}$ & $-0.35^{\mathrm{a}}$ & $-0.41^{\mathrm{a}}$ & $-0.46^{\mathrm{a}}$ & $-0.56^{\mathrm{a}}$ & $-0.54^{\mathrm{a}}$ & $-0.63^{\mathrm{a}}$ & $-0.57^{\mathrm{a}}$ & $-0.68^{\mathrm{a}}$ & $-0.56^{\mathrm{a}}$ & $-0.70^{\mathrm{a}}$ & $-0.61^{\mathrm{a}}$ & $-0.46^{\mathrm{a}}$ \\
\hline $\begin{array}{l}0-6 \text { months } \\
\text { Mothers Education }\end{array}$ & Reference & Reference & Reference & Reference & Reference & Reference & Reference & Reference & Reference & Reference & Reference & Reference & Reference & Reference \\
\hline No education & $-0.79^{\mathrm{a}}$ & $-0.50^{\mathrm{a}}$ & $-0.64^{\mathrm{a}}$ & $-0.55^{\mathrm{a}}$ & $-0.51^{a}$ & $-0.58^{a}$ & $-0.55^{\mathrm{a}}$ & $-0.63^{a}$ & $-0.42^{\mathrm{a}}$ & $-0.51^{a}$ & $-0.26^{\mathrm{b}}$ & $-0.52^{\mathrm{a}}$ & -0.04 & $-0.57^{a}$ \\
\hline$<5$ years & $-0.90^{\mathrm{a}}$ & -0.19 & $-0.59^{a}$ & -0.14 & $-0.47^{a}$ & $-0.28^{\mathrm{a}}$ & $-0.58^{a}$ & $-0.37^{a}$ & $-0.42^{\mathrm{a}}$ & $-0.31^{\mathrm{a}}$ & -0.2 & $-0.26^{\mathrm{c}}$ & -0.03 & -0.12 \\
\hline $5-7$ years & $-0.31^{\mathrm{b}}$ & $-0.30^{\mathrm{b}}$ & $-0.24^{\mathrm{a}}$ & $-0.36^{\mathrm{a}}$ & $-0.24^{\mathrm{a}}$ & $-0.40^{\mathrm{a}}$ & $-0.32^{\mathrm{a}}$ & $-0.50^{\mathrm{a}}$ & $-0.30^{\mathrm{a}}$ & $-0.41^{\mathrm{a}}$ & $-0.29^{b}$ & $-0.42^{\mathrm{a}}$ & -0.16 & $-0.39^{\mathrm{b}}$ \\
\hline $8-9$ years & $-0.31^{\mathrm{b}}$ & -0.15 & $-0.21^{b}$ & -0.14 & $-0.18^{b}$ & $-0.24^{\mathrm{a}}$ & $-0.24^{\mathrm{a}}$ & $-0.39^{a}$ & $-0.21^{\mathrm{a}}$ & $-0.34^{\mathrm{a}}$ & -0.19 & $-0.33^{\mathrm{a}}$ & 0.06 & -0.11 \\
\hline $10-11$ years & -0.12 & $-0.21^{\mathrm{c}}$ & 0.05 & -0.13 & -0.07 & $-0.15^{\mathrm{c}}$ & $-0.17^{\mathrm{a}}$ & $-0.33^{\mathrm{a}}$ & $-0.22^{\mathrm{a}}$ & $-0.27^{\mathrm{a}}$ & -0.21 & $-0.29^{b}$ & 0.07 & $-0.33^{\mathrm{b}}$ \\
\hline$>12$ years & Reference & Reference & Reference & Reference & Reference & Reference & Reference & Reference & Reference & Reference & Reference & Reference & Reference & Reference \\
\hline $\begin{array}{l}\text { Size at birth } \\
\text { (Small) }\end{array}$ & $32^{\mathrm{a}}$ & $-0.31^{a}$ & $-0.35^{\mathrm{a}}$ & $-0.39^{a}$ & $-0.35^{\mathrm{a}}$ & $-0.40^{\mathrm{a}}$ & $-0.27^{\mathrm{a}}$ & $-0.45^{a}$ & $-0.19^{\mathrm{a}}$ & $-0.44^{a}$ & $-0.19^{b}$ & $-0.42^{\mathrm{a}}$ & -0.13 & $-0.49^{a}$ \\
\hline Average & -0.11 & -0.03 & $-0.10^{c}$ & -0.03 & $-0.12^{\mathrm{a}}$ & $-0.10^{\mathrm{b}}$ & -0.06 & $-0.15^{\mathrm{a}}$ & -0.03 & $-0.19^{a}$ & -0.08 & $-0.16^{\mathrm{b}}$ & 0.01 & $-0.18^{c}$ \\
\hline $\begin{array}{l}\text { Large } \\
\text { Type of caste }\end{array}$ & Reference & Reference & Reference & Reference & Reference & Reference & Reference & Reference & Reference & Reference & Reference & Reference & Reference & Reference \\
\hline SC & -0.1 & -0.11 & $-0.16^{\mathrm{b}}$ & $-0.23^{a}$ & $-0.24^{a}$ & $-0.24^{\mathrm{a}}$ & $-0.24^{a}$ & $-0.23^{a}$ & $-0.25^{\mathrm{a}}$ & $-0.23^{\mathrm{a}}$ & -0.09 & $-0.19^{b}$ & 0.04 & 0.01 \\
\hline ST & 0.04 & -0.04 & 0.01 & -0.09 & 0.05 & -0.06 & $0.09^{\mathrm{c}}$ & -0.04 & $0.16^{\mathrm{a}}$ & -0.07 & $0.34^{\mathrm{a}}$ & 0.14 & $0.54^{\mathrm{a}}$ & $0.41^{\mathrm{a}}$ \\
\hline $\mathrm{OBC}$ & $-0.14^{c}$ & -0.1 & $-0.14^{\mathrm{a}}$ & $-0.17^{\mathrm{a}}$ & $-0.13^{\mathrm{a}}$ & $-0.15^{\mathrm{a}}$ & $-0.12^{\mathrm{a}}$ & $-0.15^{\mathrm{a}}$ & $-0.12^{\mathrm{b}}$ & $-0.14^{\mathrm{a}}$ & 0.01 & -0.05 & 0.05 & 0.12 \\
\hline $\begin{array}{l}\text { Other caste } \\
\text { Birth order }\end{array}$ & Reference & Reference & Reference & Reference & Reference & Reference & Reference & Reference & Reference & Reference & Reference & Reference & Reference & Reference \\
\hline (4 or $\mathrm{m}$ & $25^{\mathrm{a}}$ & $-0.51^{a}$ & $-0.29^{a}$ & $-0.37^{\mathrm{a}}$ & $-0.25^{\mathrm{a}}$ & $-0.25^{\mathrm{a}}$ & $-0.18^{\mathrm{a}}$ & $-0.18^{a}$ & $-0.16^{\mathrm{a}}$ & -0.08 & -0.07 & $0.14^{\mathrm{c}}$ & 0.09 & $0.34^{\mathrm{a}}$ \\
\hline Three & .15 & $-0.24^{a}$ & $-0.18^{\mathrm{a}}$ & $-0.17^{b}$ & $-0.11^{\mathrm{b}}$ & $-0.16^{a}$ & -0.05 & $-0.15^{a}$ & -0.03 & $-0.12^{\mathrm{b}}$ & 0.04 & -0.05 & 0.05 & $0.23^{\mathrm{c}}$ \\
\hline Second & -0.04 & $-0.22^{\mathrm{a}}$ & -0.08 & -0.07 & $-0.11^{\mathrm{b}}$ & -0.05 & -0.04 & $-0.09^{\mathrm{b}}$ & -0.03 & -0.01 & 0.02 & 0.04 & 0.01 & -0.03 \\
\hline $\begin{array}{l}\text { First } \\
\text { Mothers nutrition }\end{array}$ & Reference & Reference & Reference & Reference & Reference & Reference & Reference & Reference & Reference & Reference & Reference & Reference & Reference & Reference \\
\hline BMI $<18.5$ & -0.07 & $-0.14^{b}$ & $-0.08^{c}$ & $-0.14^{b}$ & $-0.16^{a}$ & $-0.17^{\mathrm{a}}$ & $-0.21^{\mathrm{a}}$ & $-0.18^{\mathrm{a}}$ & $-0.18^{\mathrm{a}}$ & $-0.18^{\mathrm{a}}$ & $-0.29^{\mathrm{a}}$ & -0.18 & $-0.41^{\mathrm{a}}$ & $-0.24^{a}$ \\
\hline $\mathrm{BMI}>25$ & 0.11 & 0.08 & $0.16^{\mathrm{b}}$ & 0.07 & $0.18^{\mathrm{a}}$ & 0.09 & $0.16^{\mathrm{a}}$ & $0.12^{\mathrm{b}}$ & $0.25^{\mathrm{a}}$ & 0.11 & $0.27^{\mathrm{b}}$ & 0.01 & 0.01 & -0.07 \\
\hline $\begin{array}{l}\text { BMI 18.5-25 } \\
\text { Wealth Index }\end{array}$ & Reference & Reference & Reference & Reference & Reference & Reference & Reference & Reference & Reference & Reference & Reference & Reference & Reference & Reference \\
\hline (Poorest) & $-0.73^{\mathrm{a}}$ & $-0.72^{\mathrm{a}}$ & $-0.79^{\mathrm{a}}$ & $-0.82^{\mathrm{a}}$ & $-0.73^{\mathrm{a}}$ & $-0.80^{\mathrm{a}}$ & $-0.64^{\mathrm{a}}$ & $-0.66^{a}$ & $-0.64^{\mathrm{a}}$ & $-0.61^{\mathrm{a}}$ & $-0.54^{\mathrm{a}}$ & $-0.53^{\mathrm{a}}$ & $-0.67^{\mathrm{a}}$ & $-0.46^{\mathrm{a}}$ \\
\hline Poorer & $-0.52^{\mathrm{a}}$ & $-0.73^{\mathrm{a}}$ & $-0.52^{\mathrm{a}}$ & $-0.71^{\mathrm{a}}$ & $-0.52^{a}$ & $-0.60^{\mathrm{a}}$ & $-0.48^{a}$ & $-0.57^{a}$ & $-0.46^{\mathrm{a}}$ & $-0.50^{\mathrm{a}}$ & $-0.44^{a}$ & $-0.47^{\mathrm{a}}$ & $-0.47^{\mathrm{a}}$ & $-0.43^{\mathrm{a}}$ \\
\hline Middle & $-0.40^{\mathrm{a}}$ & $-0.50^{\mathrm{a}}$ & $-0.49^{a}$ & $-0.53^{\mathrm{a}}$ & $-0.42^{\mathrm{a}}$ & $-0.48^{a}$ & $-0.39^{a}$ & $-0.31^{\mathrm{a}}$ & $-0.38^{\mathrm{a}}$ & $-0.37^{a}$ & $-0.31^{a}$ & $-0.44^{a}$ & $-0.43^{\mathrm{b}}$ & $-0.52^{\mathrm{a}}$ \\
\hline Richer & $-0.46^{\mathrm{a}}$ & $-0.26^{\mathrm{b}}$ & $-0.40^{\mathrm{a}}$ & $-0.30^{\mathrm{a}}$ & $-0.26^{\mathrm{a}}$ & $-0.30^{\mathrm{a}}$ & $-0.24^{\mathrm{a}}$ & $-0.20^{\mathrm{a}}$ & $-0.25^{\mathrm{a}}$ & $-0.22^{\mathrm{a}}$ & -0.16 & $-0.22^{\mathrm{b}}$ & $-0.38^{b}$ & $-0.40^{\mathrm{a}}$ \\
\hline Richest & Reference & Reference & Reference & Reference & Reference & Reference & Reference & Reference & Reference & Reference & Reference & Reference & Reference & Reference \\
\hline
\end{tabular}

a: $1 \%$ Significance; b: $5 \%$ Significance; c: $10 \%$ Significance 
Table 5: Quantile Regression Estimations for the different quantiles of the Female (61582) and Male (66018) children's, Dependent variable HAZ (Stunting). NFHS-4

\begin{tabular}{|c|c|c|c|c|c|c|c|c|c|c|c|c|c|c|}
\hline \multirow[t]{2}{*}{ Parameter } & \multicolumn{2}{|c|}{0.05} & \multicolumn{2}{|c|}{0.1} & \multicolumn{2}{|c|}{0.25} & \multicolumn{2}{|c|}{0.5} & \multicolumn{2}{|c|}{0.75} & \multicolumn{2}{|c|}{0.9} & \multicolumn{2}{|c|}{0.95} \\
\hline & Female & Male & Female & Male & Female & Male & Female & Male & Female & Male & Female & Male & Female & Male \\
\hline $\begin{array}{l}\text { Intercept } \\
\text { Child age }\end{array}$ & $-2.72^{\mathrm{a}}$ & $-3.28^{a}$ & $-1.87^{\mathrm{a}}$ & $-2.36^{a}$ & $-0.66^{a}$ & $-0.95^{\mathrm{a}}$ & $0.41^{\mathrm{a}}$ & $0.26^{\mathrm{a}}$ & $1.54^{\mathrm{a}}$ & $1.37^{\mathrm{a}}$ & $2.73^{\mathrm{a}}$ & $2.49^{\mathrm{a}}$ & $3.56^{\mathrm{a}}$ & $3.29^{\mathrm{a}}$ \\
\hline 25-36 in Months & $-0.50^{\mathrm{a}}$ & $-0.12^{\mathrm{a}}$ & $-0.67^{\mathrm{a}}$ & $-0.36^{\mathrm{a}}$ & $-1.02^{\mathrm{a}}$ & $-0.82^{\mathrm{a}}$ & $-1.23^{\mathrm{a}}$ & $-1.15^{\mathrm{a}}$ & $-1.41^{\mathrm{a}}$ & $-1.36^{\mathrm{a}}$ & $-1.42^{\mathrm{a}}$ & $-1.41^{\mathrm{a}}$ & $-1.37^{\mathrm{a}}$ & $-1.37^{\mathrm{a}}$ \\
\hline 13-24 months & $-0.52^{\mathrm{a}}$ & $-0.41^{\mathrm{a}}$ & $-0.68^{\mathrm{a}}$ & $-0.59^{\mathrm{a}}$ & $-1.00^{\mathrm{a}}$ & $-1.00^{\mathrm{a}}$ & $-1.15^{\mathrm{a}}$ & $-1.21^{\mathrm{a}}$ & $-1.27^{\mathrm{a}}$ & $-1.28^{\mathrm{a}}$ & $-1.20^{\mathrm{a}}$ & $-1.26^{\mathrm{a}}$ & $-1.19^{\mathrm{a}}$ & $-1.15^{\mathrm{a}}$ \\
\hline 7-12 months & -0.07 & $-0.11^{\mathrm{b}}$ & $-0.13^{a}$ & $-0.11^{\mathrm{a}}$ & $-0.28^{a}$ & $-0.29^{a}$ & $-0.35^{\mathrm{a}}$ & $-0.35^{\mathrm{a}}$ & $-0.38^{\mathrm{a}}$ & $-0.37^{a}$ & $-0.32^{\mathrm{a}}$ & $-0.30^{\mathrm{a}}$ & $-0.27^{a}$ & $-0.28^{\mathrm{a}}$ \\
\hline $\begin{array}{l}0-6 \text { months } \\
\text { Mothers Education }\end{array}$ & Reference & Reference & Reference & Reference & Reference & Reference & Reference & Reference & Reference & Reference & Reference & Reference & Reference & Reference \\
\hline No education & $-0.50^{\mathrm{a}}$ & $-0.46^{\mathrm{a}}$ & $-0.53^{\mathrm{a}}$ & $-0.46^{\mathrm{a}}$ & $-0.48^{\mathrm{a}}$ & $-0.47^{\mathrm{a}}$ & $-0.43^{\mathrm{a}}$ & $-0.46^{\mathrm{a}}$ & $-0.34^{a}$ & $-0.42^{\mathrm{a}}$ & $-0.27^{\mathrm{a}}$ & $-0.31^{\mathrm{a}}$ & -0.15 & $-0.31^{a}$ \\
\hline$<5$ years & $-0.34^{\mathrm{a}}$ & $-0.27^{\mathrm{a}}$ & $-0.36^{\mathrm{a}}$ & $-0.26^{\mathrm{a}}$ & $-0.37^{\mathrm{a}}$ & $-0.31^{a}$ & $-0.32^{\mathrm{a}}$ & $-0.35^{\mathrm{a}}$ & $-0.32^{\mathrm{a}}$ & $-0.38^{\mathrm{a}}$ & $-0.26^{\mathrm{a}}$ & $-0.40^{\mathrm{a}}$ & $-0.30^{\mathrm{b}}$ & $-0.38^{\mathrm{a}}$ \\
\hline 5-7 years & $-0.30^{\mathrm{a}}$ & $-0.24^{\mathrm{a}}$ & $-0.30^{\mathrm{a}}$ & $-0.29^{\mathrm{a}}$ & $-0.30^{\mathrm{a}}$ & $-0.32^{\mathrm{a}}$ & $-0.31^{\mathrm{a}}$ & $-0.31^{\mathrm{a}}$ & $-0.29^{\mathrm{a}}$ & $-0.33^{\mathrm{a}}$ & $-0.24^{\mathrm{a}}$ & $-0.30^{\mathrm{a}}$ & $-0.17^{\mathrm{c}}$ & $-0.29^{\mathrm{a}}$ \\
\hline $8-9$ years & $-0.09^{\mathrm{c}}$ & -0.07 & $-0.17^{\mathrm{a}}$ & $-0.12^{\mathrm{a}}$ & $-0.21^{\mathrm{a}}$ & $-0.17^{\mathrm{a}}$ & $-0.25^{\mathrm{a}}$ & $-0.22^{\mathrm{a}}$ & $-0.24^{\mathrm{a}}$ & $-0.24^{\mathrm{a}}$ & $-0.24^{\mathrm{a}}$ & $-0.27^{\mathrm{a}}$ & $-0.20^{\mathrm{b}}$ & $-0.30^{\mathrm{a}}$ \\
\hline $10-11$ years & -0.01 & -0.08 & $-0.10^{\mathrm{b}}$ & $-0.08^{c}$ & $-0.11^{a}$ & $-0.09^{a}$ & $-0.11^{\mathrm{a}}$ & $-0.12^{\mathrm{a}}$ & $-0.12^{\mathrm{a}}$ & $-0.10^{\mathrm{a}}$ & $-0.10^{c}$ & -0.07 & -0.08 & -0.1 \\
\hline $\begin{array}{l}>12 \text { years } \\
\text { Size at birth }\end{array}$ & Reference & Reference & Reference & Reference & Reference & Reference & Reference & Reference & Reference & Reference & Reference & Reference & Reference & Reference \\
\hline (Small) & $-0.35^{\mathrm{a}}$ & $-0.22^{\mathrm{a}}$ & $-0.36^{a}$ & $-0.27^{\mathrm{a}}$ & $-0.36^{a}$ & $-0.41^{a}$ & $-0.41^{\mathrm{a}}$ & $-0.45^{\mathrm{a}}$ & $-0.48^{\mathrm{a}}$ & $-0.47^{a}$ & $-0.61^{a}$ & $-0.54^{a}$ & $-0.64^{a}$ & $-0.62^{a}$ \\
\hline Average & 0.02 & -0.02 & -0.002 & -0.04 & $-0.05^{\mathrm{b}}$ & $-0.11^{\mathrm{a}}$ & $-0.08^{a}$ & $-0.13^{\mathrm{a}}$ & $-0.13^{\mathrm{a}}$ & $-0.17^{\mathrm{a}}$ & $-0.2^{\mathrm{a}}$ & $-0.24^{\mathrm{a}}$ & $-0.19^{\mathrm{b}}$ & $-0.29^{\mathrm{a}}$ \\
\hline $\begin{array}{l}\text { Large } \\
\text { Type of cast }\end{array}$ & Reference & Reference & Reference & Reference & Reference & Reference & Reference & Reference & Reference & Reference & Reference & Reference & Reference & Reference \\
\hline (SC) & $-0.10^{\mathrm{b}}$ & $-0.19^{a}$ & $-0.17^{\mathrm{a}}$ & $-0.24^{\mathrm{a}}$ & $-0.20^{\mathrm{a}}$ & $-0.23^{\mathrm{a}}$ & $-0.24^{\mathrm{a}}$ & $-0.22^{\mathrm{a}}$ & $-0.24^{a}$ & $-0.22^{\mathrm{a}}$ & $-0.21^{a}$ & $-0.19^{\mathrm{a}}$ & $-0.31^{\mathrm{a}}$ & $-0.13^{\mathrm{c}}$ \\
\hline ST & 0.01 & $-0.20^{\mathrm{a}}$ & -0.01 & $-0.18^{\mathrm{a}}$ & 0.001 & $-0.09^{\mathrm{a}}$ & 0.02 & $-0.07^{\mathrm{a}}$ & $0.05^{\mathrm{c}}$ & $-0.07^{a}$ & $0.14^{\mathrm{a}}$ & 0.05 & $0.29^{\mathrm{a}}$ & $0.18^{b}$ \\
\hline OBC & -0.06 & $-0.12^{\mathrm{a}}$ & $-0.12^{\mathrm{a}}$ & $-0.14^{\mathrm{a}}$ & $-0.15^{\mathrm{a}}$ & $-0.16^{\mathrm{a}}$ & $-0.16^{a}$ & $-0.16^{\mathrm{a}}$ & $-0.18^{\mathrm{a}}$ & $-0.20^{\mathrm{a}}$ & $-0.16^{\mathrm{a}}$ & $-0.22^{\mathrm{a}}$ & $-0.17^{\mathrm{b}}$ & $-0.23^{\mathrm{a}}$ \\
\hline Other caste & Reference & Reference & Reference & Reference & Reference & Reference & Reference & Reference & Reference & Reference & Reference & Reference & Reference & Reference \\
\hline $\begin{array}{l}\text { Birth order } \\
(4 \text { or more })\end{array}$ & $-0.30^{\mathrm{a}}$ & $-0.12^{\mathrm{b}}$ & $-0.25^{\mathrm{a}}$ & $-0.14^{a}$ & $-0.23^{\mathrm{a}}$ & $-0.16^{\mathrm{a}}$ & $-0.21^{\mathrm{a}}$ & $-0.12^{\mathrm{a}}$ & $-0.18^{a}$ & $-0.11^{\mathrm{a}}$ & $-0.13^{\mathrm{a}}$ & -0.02 & -0.1 & 0.07 \\
\hline Three & $-0.17^{\mathrm{a}}$ & $-0.10^{\mathrm{b}}$ & $-0.18^{\mathrm{a}}$ & $-0.11^{\mathrm{a}}$ & $-0.15^{\mathrm{a}}$ & $-0.10^{\mathrm{a}}$ & $-0.14^{a}$ & $-0.09^{\mathrm{a}}$ & $-0.11^{\mathrm{a}}$ & $-0.07^{\mathrm{a}}$ & -0.06 & -0.04 & 0.03 & 0.02 \\
\hline Second & $-0.08^{\mathrm{b}}$ & 0.02 & $-0.10^{\mathrm{a}}$ & -0.03 & $-0.07^{\mathrm{a}}$ & $-0.06^{\mathrm{a}}$ & $-0.07^{\mathrm{a}}$ & $-0.04^{b}$ & $-0.05^{\mathrm{b}}$ & -0.03 & $-0.08^{\mathrm{b}}$ & 0.03 & -0.01 & $0.10^{c}$ \\
\hline $\begin{array}{l}\text { First } \\
\text { Mothers BMI }\end{array}$ & Reference & Reference & Reference & Reference & Reference & Reference & Reference & Reference & Reference & Reference & Reference & Reference & Reference & Reference \\
\hline BMI $<18.5$ & $-0.11^{\mathrm{a}}$ & $-0.06^{c}$ & $-0.13^{a}$ & $-0.10^{\mathrm{a}}$ & $-0.16^{\mathrm{a}}$ & $-0.15^{a}$ & $-0.20^{\mathrm{a}}$ & $-0.19^{a}$ & $-0.27^{\mathrm{a}}$ & $-0.21^{\mathrm{a}}$ & $-0.42^{\mathrm{a}}$ & $-0.34^{a}$ & $-0.57^{\mathrm{a}}$ & $-0.46^{\mathrm{a}}$ \\
\hline $\mathrm{BMI}>25$ & $0.28^{\mathrm{a}}$ & $0.26^{\mathrm{a}}$ & $0.24^{\mathrm{a}}$ & $0.25^{\mathrm{a}}$ & $0.20^{\mathrm{a}}$ & $0.19^{\mathrm{a}}$ & $0.15^{\mathrm{a}}$ & $0.13^{\mathrm{a}}$ & $0.09^{\mathrm{a}}$ & $0.12^{\mathrm{a}}$ & 0.02 & $0.08^{c}$ & -0.11 & 0.03 \\
\hline $\begin{array}{l}\text { BMI 18.5-25 } \\
\text { Wealth Index }\end{array}$ & Reference & Reference & Reference & Reference & Reference & Reference & Reference & Reference & Reference & Reference & Reference & Reference & Reference & Reference \\
\hline (Poorest) & $-0.62^{\mathrm{a}}$ & $-0.56^{a}$ & $-0.67^{a}$ & $-0.62^{\mathrm{a}}$ & $-0.68^{\mathrm{a}}$ & $-0.63^{\mathrm{a}}$ & $-0.60^{\mathrm{a}}$ & $-0.58^{a}$ & $-0.57^{\mathrm{a}}$ & $-0.51^{a}$ & $-0.54^{a}$ & $-0.47^{\mathrm{a}}$ & $-0.53^{\mathrm{a}}$ & $-0.46^{\mathrm{a}}$ \\
\hline Poorer & $-0.48^{\mathrm{a}}$ & $-0.31^{\mathrm{a}}$ & $-0.47^{\mathrm{a}}$ & $-0.40^{\mathrm{a}}$ & $-0.46^{\mathrm{a}}$ & $-0.39^{a}$ & $-0.45^{\mathrm{a}}$ & $-0.38^{\mathrm{a}}$ & $-0.46^{\mathrm{a}}$ & $-0.39^{\mathrm{a}}$ & $-0.47^{\mathrm{a}}$ & $-0.42^{\mathrm{a}}$ & $-0.46^{\mathrm{a}}$ & $-0.39^{\mathrm{a}}$ \\
\hline Middle & $-0.31^{\mathrm{a}}$ & $-0.20^{\mathrm{a}}$ & $-0.33^{a}$ & $-0.17^{\mathrm{a}}$ & $-0.32^{\mathrm{a}}$ & $-0.23^{\mathrm{a}}$ & $-0.32^{\mathrm{a}}$ & $-0.25^{\mathrm{a}}$ & $-0.34^{a}$ & $-0.24^{a}$ & $-0.38^{a}$ & $-0.25^{\mathrm{a}}$ & $-0.34^{a}$ & $-0.18^{b}$ \\
\hline Richer & $-0.20^{\mathrm{a}}$ & -0.08 & $-0.18^{a}$ & $-0.09^{\mathrm{b}}$ & $-0.19^{\mathrm{a}}$ & $-0.10^{\mathrm{a}}$ & $-0.17^{a}$ & $-0.11^{\mathrm{a}}$ & $-0.20^{\mathrm{a}}$ & $-0.12^{\mathrm{a}}$ & $-0.30^{\mathrm{a}}$ & $-0.11^{\mathrm{b}}$ & $-0.23^{b}$ & -0.07 \\
\hline Richest & Reference & Reference & Reference & Reference & Reference & Reference & Reference & Reference & Reference & Reference & Reference & Reference & Reference & Reference \\
\hline
\end{tabular}


Figure 1: LMS curves for child aged 0-36 months in NFHS 1 (1992) and NFHS 4 (2016)

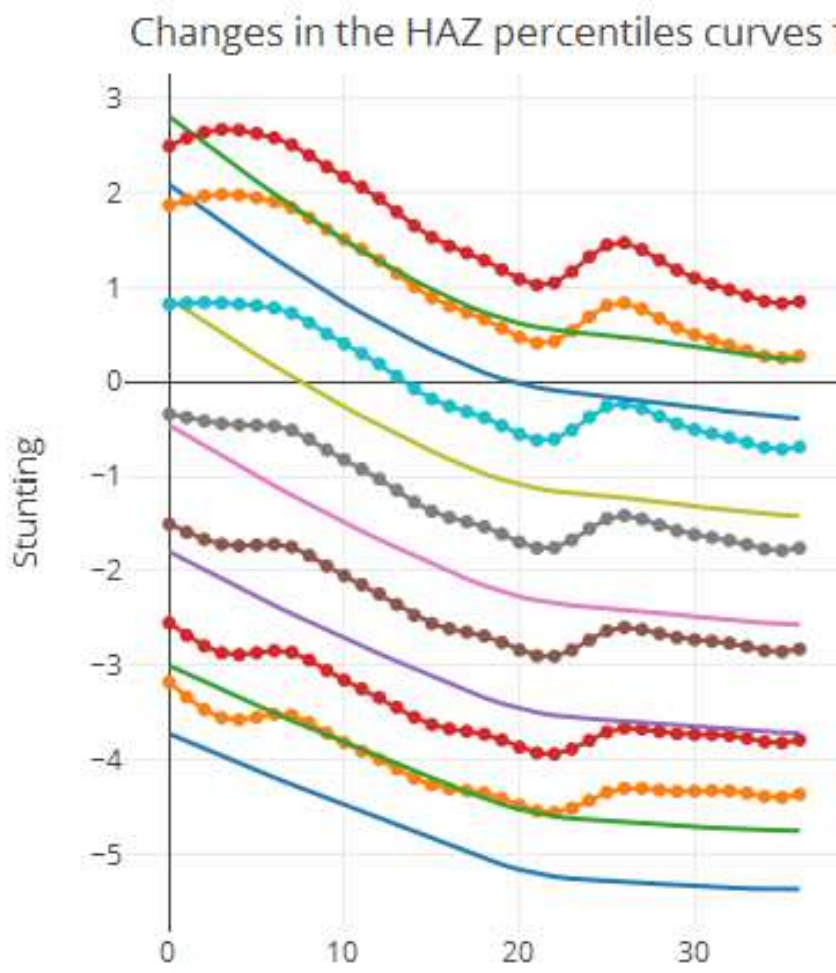

Age in months $0-36$

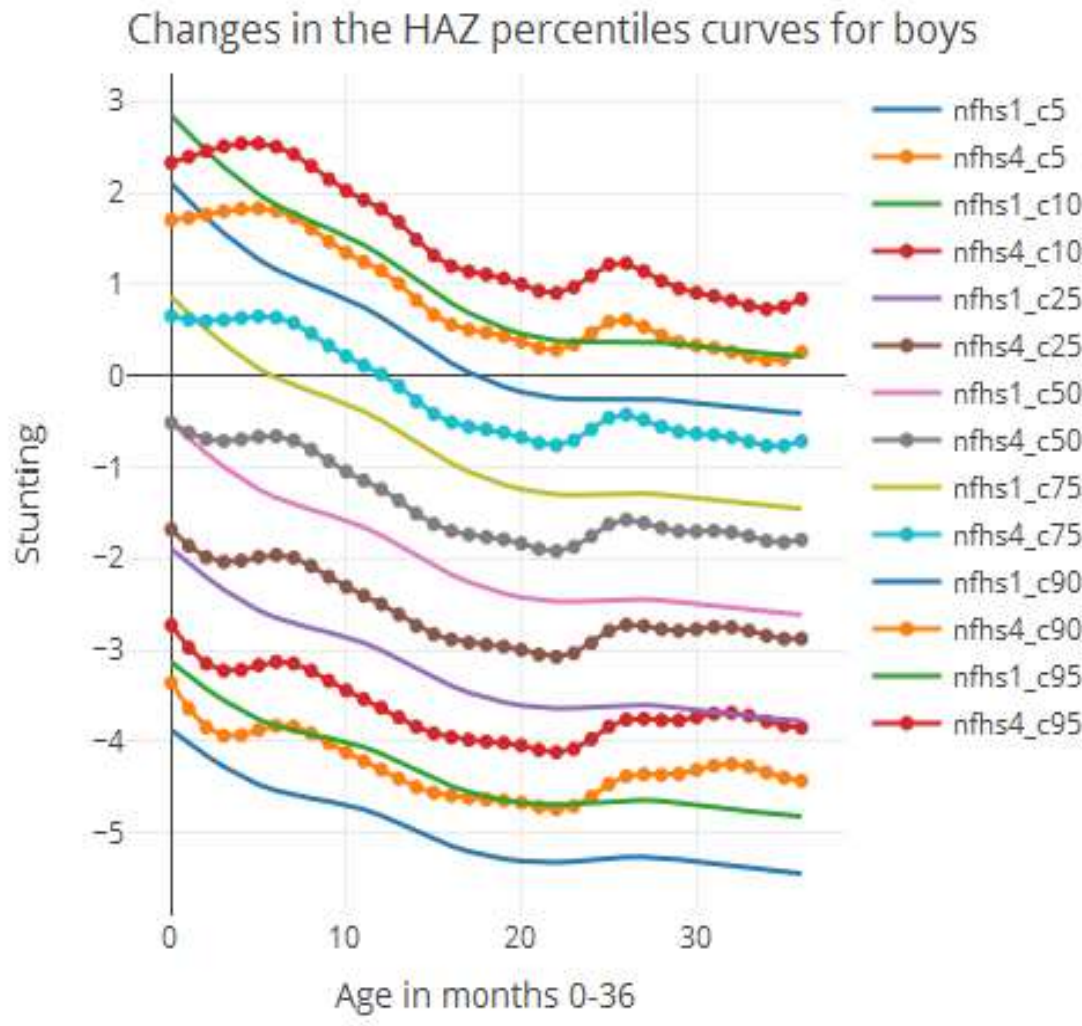




\section{References}

1. Sahu SK, Kumar SG, Bhat BV, Premarajan KC, Sarkar S, Roy G, et al. malnutrition among under-five children in India and strategies for control. J Nat Sci Biol Med. 2015;6:18-23. doi:10.4103/0976-9668.149072.

2. Agency IAE, Sous-emploi A d'Execution des T d'Interet $\mathrm{P}$ contre le. Child nutrition in Senegal. https://inis.iaea.org/search/search.aspx?orig_q=RN:34028299. Accessed 31 Mar 2020 .

3. Mokalla TR, Mendu VVR. Risk factors and socioeconomic inequalities in undernutrition among children 0-59 months of age in India. Int $\mathbf{J}$ Popul Stud. 2020;5. doi:10.18063/ijps.v5i2.1125.

4. UNDP 2002. Introduction The Issues of Public Health and Medical Systems in Developing Countries. 2002;:1-7.

5. Markos Z. Predicting Under Nutrition Status of Under-Five Children Using Data Mining Techniques: The Case of 2011 Ethiopian Demographic and Health Survey. J Heal Med Informatics. 2014;5. doi:10.4172/2157-7420.1000152.

6. Risk NCD, Collaboration F, WHO, Whelton H, Harrington JM, Crowley E, et al. Boychart042. Lancet. 2016;:1-51.

7. Islam MR, Rahman MS, Rahman MM, Nomura S, De Silva A, Lanerolle P, et al. Reducing childhood malnutrition in Bangladesh: The importance of addressing socioeconomic inequalities. Public Health Nutr. 2020;23:72-82.

8. Khan S, Zaheer S, Safdar NF. Determinants of stunting, underweight and wasting among children < 5 years of age: Evidence from 2012-2013 Pakistan demographic and health survey. BMC Public Health. 2019;19.

9. International Institute for population Studies. National Family Health Survey - 4: 2015-16, India Fact sheet. In: National Family Health Survey - 4: 2015-16. 2016. p. 1-6. http://rchiips.org/NFHS/pdf/NFHS4/India.pdf. Accessed 22 Feb 2018.

10. Anon. Improving Child Nutrition - The achievable imperative for global progress. United Nations Children's fund. 2013. doi:978-92-806-4686-3.

11. World Health Organization (WHO). Stunting | UNICEF. 2013;:39. http://unicef.in/whatwedo/10/stunting. Accessed 19 Feb 2020.

12. WHO Multicentre Growth Reference Study Group. WHO Child Growth Standards. 2009.

13. Shiratori, Sakiko. Determinants of Child Malnutrition in Tanzania: a Quantile Regression Approach. 2014 Annu Meet July 27-29, 2014, Minneapolis, Minnesota. 2014.

14. Oruamabo RS. Child malnutrition and the Millennium Development Goals: Much haste 
but less speed? Arch Dis Child. 2015;100:S19-22. doi:10.1136/archdischild-2013-305384.

15. Qu P, Mi B, Wang D, Zhang R, Yang J, Liu D, et al. Association between the Infant and child feeding Index (ICFI) and nutritional status of 6- to 35-month-old children in rural western China. PLoS One. 2017;12:e0171984. doi:10.1371/journal.pone.0171984.

16. Aber JL, Bennett NG, Conley DC, Li J. The Effects of Poverty on Child Health and Development. Annu Rev Public Health. 1997;18:463-83. doi:10.1146/annurev.publhealth.18.1.463.

17. PEDIATRICS COC. Poverty and child health in the United States. Pediatrics. 2016;137. 18. Gupta N, Zurn P, Diallo K, Dal Poz MR. Uses of population census data for monitoring geographical imbalance in the health workforce: Snapshots from three developing countries. Int J Equity Health. 2003;2:1-12. doi:10.1186/1475-9276-2-1.

19. Jukes M. The long-term impact of preschool health and nutrition on education. Food and Nutrition Bulletin. 2005;26 2 SUPPL. 2:23-37. doi:10.1177/15648265050262S210.

20. Bassole L, Bassole L, Bond S, Fapchamps M, Leibbrandt M, Nssah BE, et al. "Opportunities and Challenges of Development for Africa in the Global Arena" A Quantile Regression Analysis public infrastructure really matter? a Quantile Regression Analysis. http://repository.uneca.org/bitstream/handle/10855/15005/bib-58080.pdf?sequence=1. Accessed 19 Mar 2018.

21. Kumar A, Kumari D, Singh A. Increasing socioeconomic inequality in childhood undernutrition in urban India: Trends between 1992-93, 1998-99 and 2005-06. Health Policy Plan. 2015;30:1003-16. doi:10.1093/heapol/czu104.

22. Corsi DJ, Mejía-Guevara I, Subramanian S V. Risk factors for chronic undernutrition among children in India: Estimating relative importance, population attributable risk and fractions. Soc Sci Med. 2016;157:165-85.

23. Mishra S, Pandey CM, Chaubey YP, Singh U. Determinants of Child Malnutrition in Empowered Action Group (EAG) States of India. Stat Appl. 2015;13:2454-7395.

24. Mekonnen T, Dune T, Perz J, Ogbo FA. Trends and determinants of antenatal care service use in ethiopia between 2000 and 2016. Int J Environ Res Public Health. 2019;16.

25. Das S, Rahman RM. Application of ordinal logistic regression analysis in determining risk factors of child malnutrition in Bangladesh. Nutr J. 2011;10:1-11.

26. Messelu Y, Trueha K. Determining Risk Factors of Malnutrition among under-Five Children in Sheka Zone, South West Ethiopia Using Ordinal Logistic Regression Analysis. Public Heal Res. 2016;6:161-7. doi:10.5923/j.phr.20160606.03.

27. Li W, Liu E, BeLue R. Household water treatment and the nutritional status of primary- 
aged children in India: Findings from the India human development survey. Global Health. 2018;14. doi:10.1186/s12992-018-0356-7.

28. Talukder A. Factors Associated with Malnutrition among Under-Five Children: Illustration using Bangladesh Demographic and Health Survey, 2014 Data. Children. 2017;4:88. doi:10.3390/children4100088.

29. Das S, Rahman RM. Application of ordinal logistic regression analysis in determining risk factors of child malnutrition in Bangladesh. Nutr J. 2011;10:124. doi:10.1186/1475-2891-1012422082256.

30. Nakajyo T, Yang J, Sakai F, Aoki Y. Quantum efficiencies of Mg photocathode under illumination with 3rd and 4th harmonics Nd: LiYF4 laser light in RF gun. Japanese J Appl Physics, Part 1 Regul Pap Short Notes Rev Pap. 2003;42:1470-4.

31. Srinivasan CS, Zanello G, Shankar B. Rural-urban disparities in child nutrition in Bangladesh and Nepal. BMC Public Health. 2013;13. doi:10.1186/1471-2458-13-581.

32. IIPS. National Family Health Survey (NFHS-3), 2005-06: India. Int Inst Popul Sci Macro Int. 2007.

33. Singh S, Srivastava S, Upadhyay AK. Socioeconomic inequality in malnutrition among children in India: An analysis of 640 districts from National Family Health Survey (2015-16). Int J Equity Health. 2019;18. doi:10.1186/s12939-019-1093-0.

34. De Onis M. WHO Child Growth Standards based on length/height, weight and age. Acta Paediatr Int J Paediatr. 2006;95 SUPPL. 450:76-85.

35. Koenker R, Bassett G. Regression Quantiles. Econometrica. 1978;46:33.

36. Koenker R, Hallock KF. Quantile regression. J Econ Perspect. 2001;15:143-56.

37. Bassolé L. Child Malnutrition in Senegal : Does Access to Public Infrastructure Really Matter? A Quantile Regression Analysis. In: United Nations. Economic Commission for Africa; African Development Bank (2007-11). 2007. p. 1-27.

38. Cole TJ, Green PJ. Smoothing reference centile curves: The lms method and penalized likelihood. Stat Med. 1992;11:1305-19.

39. Yee TW. An Implementation for Regression Quantile Estimation. In: Compstat. PhysicaVerlag HD; 2002. p. 3-14. doi:10.1007/978-3-642-57489-4_1.

40. Yee TW. Quantile regression via vector generalized additive models. Stat Med. 2004;23:2295-315. doi:10.1002/sim.1822.

41. Chen C. Growth charts of body mass index (BMI) with quantile regression. In: Proceedings of the 2005 International Conference on Algorithmic Mathematics and Computer Science, AMCS'05. 2005. p. 114-20. http://www.sas.com/statistics. Accessed 9 Jul 2020. 
42. Li Y, Graubard BI, Korn EL. Application of nonparametric quantile regression to body mass index percentile curves from survey data. Stat Med. 2010;29:558-72. doi:10.1002/sim.3810.

43. Ouyang Y, Wang H, Su C, Wang Z, Song Y, Xiao Y, et al. use of quantile regression to investigate changes in the body mass index distribution of Chinese adults aged 18-60 years: A longitudinal study Biostatistics and methods. BMC Public Health. 2015;15:278.

44. Sharaf MF, Mansour EI, Rashad AS. CHILD NUTRITIONAL STATUS in EGYPT: A COMPREHENSIVE ANALYSIS of SOCIOECONOMIC DETERMINANTS USING A QUANTILE REGRESSION APPROACH. Journal of Biosocial Science. 2019;51:1-17. doi:10.1017/S0021932017000633.

45. Mani K. Determinants of Under-Five Mortality in Rural Empowered Action Group States in India: An Application of Cox Frailty Model. Int J MCH AIDS. 2012;1:60-72.

46. Vir SC. Chronic Child Undernutrition (Stunting) in India: An Overview of the Problem, Determinants and Ongoing Efforts for Improving the Situation. Stat Appl. 2019;17:221-34.

47. Khan REA, Raza MA. Determinants of Malnutrition in Indian children: new evidence from IDHS through CIAF. Qual Quant. 2016;50:299-316.

48. Mazumdar S. Determinants of inequality in child malnutrition in India: The povertyundernutrition linkage. Asian Popul Stud. 2010;6:307-33.

49. Kandala NB, Madungu TP, Emina JBO, Nzita KPD, Cappuccio FP. Malnutrition among children under the age of five in the Democratic Republic of Congo (DRC): Does geographic location matter? BMC Public Health. 2011;11:261. doi:10.1186/1471-2458-11-261.

50. Rashad AS, Sharaf MF. Economic Growth and Child Malnutrition in Egypt: New Evidence from National Demographic and Health Survey. Soc Indic Res. 2018;135:769-95. doi:10.1007/s11205-016-1515-y. 

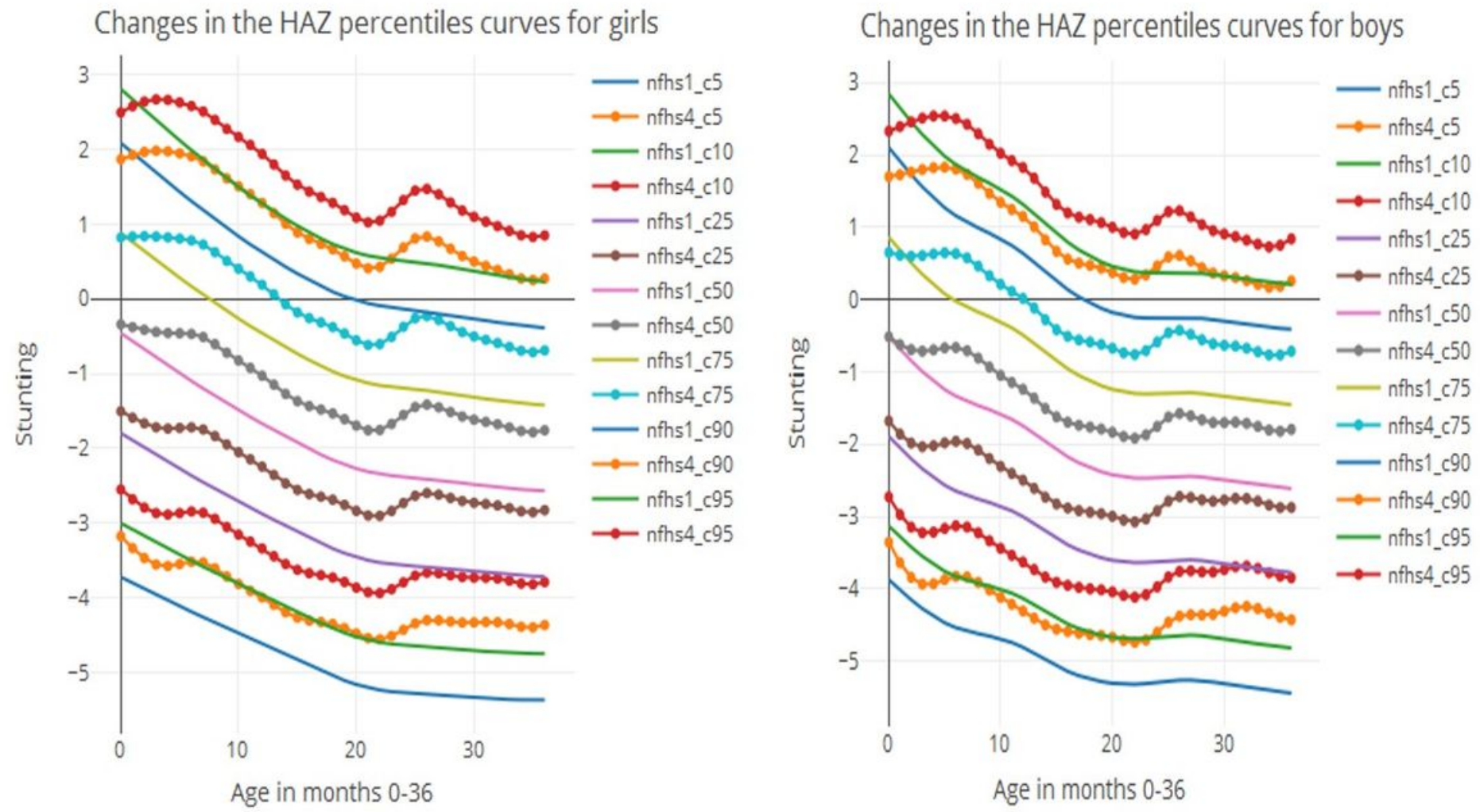

\section{Figure 1}

LMS curves for child aged 0-36 months in NFHS 1 (1992) and NFHS 4 (2016) 